\title{
Polyphenols and DNA Damage: A Mixed Blessing
}

\author{
Amaya Azqueta ${ }^{1,2, *}$ and Andrew Collins ${ }^{3}$ \\ 1 Department of Pharmacology and Toxicology, Faculty of Pharmacy, University of Navarra, C/Irunlarrea 1, \\ 31009 Pamplona, Spain \\ 2 IdiSNA, Navarra Institute for Health Research \\ 3 Department of Nutrition, Institute of Basic Medical Sciences, University of Oslo, PB 1046 Blindern, \\ 0316 Oslo, Norway; a.r.collins@medisin.uio.no \\ * Correspondence: amazqueta@unav.es; Tel.: +34-948-425-600 (ext. 806-343)
}

Received: 11 October 2016; Accepted: 23 November 2016; Published: 3 December 2016

\begin{abstract}
Polyphenols are a very broad group of chemicals, widely distributed in plant foods, and endowed with antioxidant activity by virtue of their numerous phenol groups. They are widely studied as putative cancer-protective agents, potentially contributing to the cancer preventive properties of fruits and vegetables. We review recent publications relating to human trials, animal experiments and cell culture, grouping them according to whether polyphenols are investigated in whole foods and drinks, in plant extracts, or as individual compounds. A variety of assays are in use to study genetic damage endpoints. Human trials, of which there are rather few, tend to show decreases in endogenous DNA damage and protection against DNA damage induced ex vivo in blood cells. Most animal experiments have investigated the effects of polyphenols (often at high doses) in combination with known DNA-damaging agents, and generally they show protection. High concentrations can themselves induce DNA damage, as demonstrated in numerous cell culture experiments; low concentrations, on the other hand, tend to decrease DNA damage.
\end{abstract}

Keywords: polyphenols; flavonoids; human studies; in vitro; in vivo; DNA damage; DNA protection

\section{Introduction}

For many years now it has been recognised that fruits and vegetables play an important role in preventing or alleviating the effects of various chronic diseases, notably cardiovascular disease and various cancers. The mechanism(s) of this protection is still not clear. A common explanation is the so-called antioxidant hypothesis; oxidative stress is a factor in many diseases; fruits and vegetables contain various phytochemicals with antioxidant properties, and so these are likely to be the agents of protection. This is clearly a simplistic hypothesis; phytochemicals have been shown to have a wide array of influences on the physiological processes of human cells, and reducing them to sources of antioxidant activity is misguided and misleading. A meta-analysis of clinical trials indicates that antioxidant phytochemicals taken as supplements have no beneficial effect on mortality and may even increase it [1]. In natural plant foods, of course, phytochemicals of different kinds are present, acting in concert, often in all likelihood synergistically, and so studies of whole foods or extracts are particularly valuable. The reductionist approach (looking at individual components) is still popular, however, as evidenced by the large number of studies of individual phytochemicals, and by the growing catalogue of plant species that have been extracted and tested for potential health-promoting effects using a range of molecular markers. DNA damage is one of the most commonly employed such markers, in the reasonable belief that a decrease in DNA damage-as the initiating event of carcinogenesis-must signify a decrease in cancer risk.

Currently, the most popular assay for DNA damage at the cellular level is single cell gel electrophoresis, or the comet assay [2]. It is based on the ability of a strand break (SB) to relax 
supercoiling in a loop of DNA, thus allowing the DNA to extend to the anode during electrophoresis forming a comet-like image in which the relative intensity of the comet tail reflects the break frequency. Strand breakage is a feature of some but not all kinds of DNA-damaging agent. Reactive oxygen species, in particular, tend to cause damage to DNA bases. An example of base oxidation is 8-oxo-7,8-dihydroguanine (8-OH-Gua). This is converted to a SB by the action of formamidopyrimidine DNA glycosylase (Fpg) — a bacterial repair enzyme, and a simple modification of the comet assay, incorporating an enzymic digestion of the DNA after lysis of cells in agarose-allows the detection of oxidised purines. An analogous enzyme, endonuclease III (or Nth) converts oxidised pyrimidines to SBs. In the search for antioxidant protection of cells against such damage, it is surprising that so few published studies actually use the enzyme-modified comet assay.

The measurement of resistance to $\mathrm{H}_{2} \mathrm{O}_{2}$-induced damage is a good marker of cellular antioxidant status. Typically, cells are exposed in vitro to $50-100 \mu \mathrm{M} \mathrm{H}_{2} \mathrm{O}_{2}$ for a brief period, and the yield of SBs is measured with the basic comet assay; the lower the break frequency, the higher the antioxidant status.

The base 8-OH-Gua and the nucleosides 8-OH-Guo and 8-OH-dGuo can be detected in tissues, but are more commonly measured in urine, plasma or serum, using high performance liquid chromatography (often linked with mass spectrometry) and antibody-based techniques (ELISA or immunohistochemistry). In the tables and text that follow, we use the abbreviation 8-OH-G to cover all three compounds, as the oxidised base is the common factor. They are markers of oxidative stress $[3,4]$; free 8-OH-Gua can arise through cellular DNA base excision repair, though the origin of the oxidised nucleosides is not certain.

$\gamma-\mathrm{H} 2 \mathrm{AX}$ is the phosphorylated form of histone $\mathrm{H} 2 \mathrm{AX}$, which appears at the site of DNA damage (particularly double SBs); it is detected by immunocytochemistry [5], or sometimes by immunofluorescence combined with flow cytometry [6], and is a sensitive damage indicator.

Unrepaired DNA damage can result in alterations at the level of chromosomes. Classically, chromosome aberrations (chrom abs) were studied as an index of genomic instability, but now the presence of micronuclei (MN: fragments of chromosomes or whole chromosomes that segregate as discrete bodies at mitosis) is a more common marker [7]. Both chrom abs and MN have been confirmed-in long-term human clinical studies-as prospective markers of cancer risk [8,9].

Here, we summarise the results of recent investigations of effects of polyphenols - a very broad class of phytochemicals-on DNA damage, at the level of humans, in animal experiments, and in in vitro studies using cultured (usually human) cells.

\section{Methods}

In this review, we have concentrated on papers published from 2010 to the present. We used PubMed with the followings terms in the title or abstract: polyphenols/polyphenol/flavonoids/flavonoid combined with DNA damage/DNA protection/DNA repair. We found a total of 386 papers. We have concentrated on papers where the effect of polyphenols, in the form of real food, plant extract or pure compound, is tested in cell culture, animals and humans. We have excluded papers where only gene expression was studied, papers specifically focused on other diseases than cancer, and papers, for example, with deficient experimental design. Papers in which the main interest is in the induction of apoptosis were also excluded.

The reports are summarised in tables according to whether they deal with whole foods (or drinks) (Table 1), with extracts of plants (Table 2), or with single phytochemicals (Table 3). Studies are further classified as 'in humans', 'in vivo' (animal studies), or 'in vitro' (experiments with cultured cells). Extracts and phytochemicals are, where possible, grouped according to functional, chemical or botanical relationships (such as 'tea and coffee related compounds', or 'flavonoids', or 'Lamiaceae'). We have generally excluded in vitro experiments with plants or compounds appearing in just one or two publications, unless they fall into one of these groups. 
Table 1. Effects of whole foods or drinks on various genetic damage endpoints, in humans, in animals ('in vivo'), and in cultured cells ('in vitro').

\begin{tabular}{|c|c|c|c|c|c|c|}
\hline Reference & Material Tested & Analysis & Assays & System & Concentration/Dose & Result \\
\hline \multicolumn{7}{|c|}{ In Humans } \\
\hline [10] & Orange juice & Polyphenols & 8-OH-G in urine by ELISA & Overweight/obese humans & 300 or $745 \mathrm{mg} /$ day (12 weeks) & $8-\mathrm{OH}-\mathrm{G} \downarrow$ \\
\hline [11] & Aronia-citrus juice & $\begin{array}{l}\text { Flavonones, } \\
\text { flavones, } \\
\text { antocyanins etc. }\end{array}$ & $\begin{array}{l}\text { 8-OH-G in plasma by } \\
\text { UHPLC-MS/MS }\end{array}$ & $\begin{array}{l}\text { Triathletes (supplemented and } \\
\text { placebo groups) }\end{array}$ & $200 \mathrm{~mL} /$ day (45 days) & $\begin{array}{l}\text { Inconclusive-levels of DNA damage } \\
\text { products too low }\end{array}$ \\
\hline [12] & Dark chocolate & Polyphenols & Comet assay & Healthy subjects: PBMN cells & $860 \mathrm{mg} /$ day (2 weeks) & $\begin{array}{l}\mathrm{H}_{2} \mathrm{O}_{2} \text {-induced SBs } \downarrow \\
\text { (short-term-2 }- \text { only) }\end{array}$ \\
\hline [13] & $\begin{array}{l}\text { De-alcoholised } \\
\text { wine }\end{array}$ & $\begin{array}{l}\text { Anthocyanins, } \\
\text { flavonols etc. }\end{array}$ & Comet assay with Fpg & $\begin{array}{l}\text { Post-menopausal women; } \\
\text { peripheral blood lymphocytes }\end{array}$ & $500 \mathrm{~mL} /$ day (1 month) & No effect \\
\hline [14] & $\begin{array}{l}\text { Wild blueberry } \\
\text { drink }\end{array}$ & $\begin{array}{l}\text { Phenolic acids } \\
\text { and anthocyanins }\end{array}$ & $\begin{array}{l}\text { Comet assay + Fpg; } \\
\mathrm{H}_{2} \mathrm{O}_{2} \text { resistance (comet assay); } \\
\text { DNA repair (in vitro comet assay) }\end{array}$ & $\begin{array}{l}\text { Subjects with cardiovascular risk } \\
\text { factors: PBMN cells }\end{array}$ & $\begin{array}{l}375 \mathrm{mg} \text { anthocyanins/day } \\
\text { ( } 6 \text { weeks) }\end{array}$ & $\begin{array}{l}\text { No effect on DNA SBs. Fpg-sensitive } \\
\text { sites } \downarrow ; \mathrm{H}_{2} \mathrm{O}_{2} \text { resistance } \uparrow ; \text { no effect } \\
\text { on repair }\end{array}$ \\
\hline [15] & Green tea & & Comet assay & $\begin{array}{l}\text { Healthy subjects: PBMN cells } 30 \\
60,90 \text { min after ingestion, exposed } \\
\text { ex vivo to UV(A)/VIS radiation }\end{array}$ & Single $540 \mathrm{~mL}$ dose & $\begin{array}{l}\text { Protection against UV(A)/VIS-induced } \\
\text { DNA SBs seen in 'responders' }\end{array}$ \\
\hline [16] & Honey & $\begin{array}{l}\text { Phenolic } \\
\text { compounds }\end{array}$ & Comet assay with EndoIII, Fpg & Pesticide-exposed humans & $\begin{array}{l}\text { 2-week honey supplementation } \\
\text { (50 g/day) }\end{array}$ & DNA repair $\uparrow$, EndoIII and Fpg sites $\downarrow$ \\
\hline \multicolumn{7}{|c|}{ In Vivo } \\
\hline [17] & $\begin{array}{l}\text { Chrysobalanus } \\
\text { icaco fruit }\end{array}$ & $\begin{array}{l}\text { Polyphenols, } \\
\text { Mg, Se }\end{array}$ & $\begin{array}{l}\text { Comet assay on blood and MN } \\
\text { assay on bone marrow and PBMN }\end{array}$ & Rats + Dox & Up to $0.4 \mathrm{~g} / \mathrm{kg} /$ day for 14 days & $\begin{array}{l}\text { Blood cells; DNA SBs } \downarrow \text {. Bone marrow, } \\
\text { blood cells; MN } \downarrow\end{array}$ \\
\hline [18] & $\begin{array}{l}\text { Green and } \\
\text { black teas }\end{array}$ & & 8-OH-G on liver by HPLC & Swiss albino mice $+\mathrm{Na}$ arsenite & $\begin{array}{l}2.5 \% \text { of } 0.5 \mathrm{~g} \text { dry leaves } / 5 \mathrm{~mL} \text { of } \\
\text { boiled water (equivalent to } \\
\text { human consumption of } 1 \text { cup). } \\
22 \text { days. }\end{array}$ & Protection $(8-\mathrm{OH}-\mathrm{G} \downarrow)$ \\
\hline [19] & Piquia pulp & $\begin{array}{l}\text { Phenolic } \\
\text { compounds, } \\
\text { carotenoids }\end{array}$ & $\begin{array}{l}\text { Comet assay on liver, kidney, heart } \\
\text { cells MN on bone marrow and } \\
\text { PBMN cells }\end{array}$ & Rats + Dox & $\begin{array}{l}75,150,300 \mathrm{mg} / \mathrm{kg} / \text { day for } \\
14 \text { days }\end{array}$ & $\begin{array}{l}\text { Protection against DNA SBs and MN } \\
\text { formation: lowest dose tends to be } \\
\text { most effective }\end{array}$ \\
\hline [20] & Açai pulp & $\begin{array}{l}\text { Phenolic } \\
\text { compounds, } \\
\text { carotenoids }\end{array}$ & $\begin{array}{l}\text { Comet assay on liver, kidney and } \\
\text { PBMN cells: MN on bone marrow } \\
\text { and PBMN cells }\end{array}$ & Mice + Dox & $\begin{array}{l}3.33,10,16.7 \mathrm{~g} / \mathrm{kg} / \text { day for } 1 \text { or } \\
14 \text { days }\end{array}$ & $\begin{array}{l}\text { Protection against DNA SBs and MN } \\
\text { formation: } 14 \text { days pretreatment } \\
\text { more effective }\end{array}$ \\
\hline [21] & $\begin{array}{l}\text { Cloudy apple } \\
\text { juice }\end{array}$ & Polyphenols & Comet assay on liver cells & Rats & $10 \mathrm{~mL} / \mathrm{kg} /$ day for 28 days & $\begin{array}{l}\text { DNA SBs } \uparrow \text { and no effect on } \\
\text { N-nitrosodiethylamine-induced damage }\end{array}$ \\
\hline [22] & Green tea & - & Comet assay on intestinal cells & Rats + As & $10 \mathrm{mg} / \mathrm{mL}$ in water for 28 days & Claim protection \\
\hline [23] & Spinach & Total polyphenols & Comet assay on leukocytes & Hyperlipidemic rats & $5 \%$ (powder) in diet, for 6 weeks & $\mathrm{H}_{2} \mathrm{O}_{2}$-induced DNA SBs in leukocytes $\downarrow$ \\
\hline
\end{tabular}


Table 1. Cont.

\begin{tabular}{|c|c|c|c|c|c|c|}
\hline Reference & Material Tested & Analysis & Assays & System & Concentration/Dose & Result \\
\hline \multicolumn{7}{|c|}{ In Vitro } \\
\hline [24] & Green tea & - & Comet assay with Fpg & Human PBMN cells & 7-71 $\mu \mathrm{M}$ catechins & $\begin{array}{l}\text { DNA damage } \downarrow \text { at lower concentrations } \\
\text { but } \uparrow \text { at highest concentration }\end{array}$ \\
\hline \multirow{2}{*}{ [25] } & \multirow{2}{*}{$\begin{array}{l}\text { Herbal } \\
\text { preparation }\end{array}$} & \multirow{2}{*}{ Total phenolics } & \multirow{2}{*}{ Comet assay } & YAC-1 (mouse lymphoma) cells & $1-13 \mathrm{mg} / \mathrm{mL}$ & DNA SBs $\uparrow$ at $8.7 \mathrm{mg} / \mathrm{mL}$ \\
\hline & & & & Rat fibroblasts & $1-13 \mathrm{mg} / \mathrm{mL}$ & DNA SBs $\uparrow$ at $2.2 \mathrm{mg} / \mathrm{mL}$ \\
\hline [26] & Various honeys & - & Comet assay & $\begin{array}{l}\text { HepG2 (human liver carcinoma) } \\
\text { cells treated with B(a)P, } \\
\text { PhIP, nitrosamines }\end{array}$ & $0.1-100 \mathrm{mg} / \mathrm{mL}$ & $\begin{array}{l}\text { Slight decreases in DNA SBs in most } \\
\text { cases, not dose-dependent }\end{array}$ \\
\hline
\end{tabular}

PBMN: peripheral blood mononuclear; SB: strand break; Fpg: formamidopyrimidine DNA glycosylase; UV: ultraviolet; VIS: visible; MN: micronucleus/micronuclei; Dox: doxorubicin

EndoIII: endonuclease III (Nth); 8-OH-G: 8-oxo-7,8-dihydroguanine; B(a)P: benzo(a)pyrene; PhIP: 2-amino-1-methyl-6-phenylimidazo[4,5-b]pyridine.

Table 2. Effects of plant extracts on various genetic damage endpoints, in humans, in animals ('in vivo'), and in cultured cells ('in vitro').

\begin{tabular}{|c|c|c|c|c|c|c|}
\hline Reference & Material tested & Analysis & Assays & System & Concentration/Dose & Result \\
\hline \multicolumn{7}{|c|}{ In Humans } \\
\hline [27] & $\begin{array}{l}\text { Green tea } \\
\text { polyphenols }\end{array}$ & & Urinary 8-OH-G by HPLC & $\begin{array}{l}\text { Postmenopausal women } \\
\text { with osteoporosis }\end{array}$ & $500 \mathrm{mg} /$ day (capsules, 6 months) & 8-OH-G $\downarrow$ over 6 months \\
\hline \multicolumn{7}{|c|}{ In Vivo } \\
\hline \multicolumn{7}{|c|}{ Tea-Related } \\
\hline [28] & $\begin{array}{l}\text { Green tea } \\
\text { polyphenols }\end{array}$ & & 8-OH-G in brain by $\mathrm{Ab}$ assay & Rats & $\begin{array}{l}400 \mathrm{mg} / \text { day (gastric intubation, } \\
4 \text { weeks) }\end{array}$ & $8-\mathrm{OH}-\mathrm{G} \downarrow$ \\
\hline [29] & $\begin{array}{l}\text { Green tea } \\
\text { polyphenols }\end{array}$ & $\begin{array}{l}\text { Epicatechin } \\
\text { derivatives }\end{array}$ & $\begin{array}{l}\text { CPD on skin and lymph nodes by } \\
\mathrm{Ab} \text { assay }\end{array}$ & Mice (NER+ and-) + UV & $\begin{array}{l}0.2 \% \text { in drinking water ( } 7 \text { days } \\
\text { before UV irradiation) }\end{array}$ & $\begin{array}{l}\text { Enhanced removal of CPDs in } \\
\text { NER-proficient mice }\end{array}$ \\
\hline [30] & Green tea extract & & MN in polychromatic erythrocytes & Mice $+\mathrm{Cr}(\mathrm{VI})$ & $30 \mathrm{mg} / \mathrm{kg}$ (one dose-gavage) & $\mathrm{MN} \downarrow$ \\
\hline [31] & $\begin{array}{l}\text { Green tea } \\
\text { polyphenols }\end{array}$ & & $\begin{array}{l}\text { Comet assay with Fpg on blood; } \\
\text { 8-OH-G in brain by HPLC }\end{array}$ & Rats + acrylonitrile & $\begin{array}{l}0.4 \% \text { in diet ( } 1 \text { week before } \\
\text { acrylonitrile and then } \\
\text { throughout acrylonitrile } \\
\text { treatment for } 28 \text { days) }\end{array}$ & $\downarrow$ Fpg-sensitive sites and 8-OH-G $\downarrow$ \\
\hline [32] & $\begin{array}{l}\text { Calluna vulgaris } \\
\text { polyphenol extract }\end{array}$ & & CPDs in skin by Ab assay & Mice + UV(B) & $\begin{array}{l}4 \mathrm{mg} / \mathrm{cm}^{2}(30 \mathrm{~min} \text { before } \\
\text { exposure to UV, repeated on } \\
10 \text { days) }\end{array}$ & CPDs $\downarrow$ \\
\hline [33] & $\begin{array}{l}\text { Podophyllum } \\
\text { hexandrum extract }\end{array}$ & Total phenolics & $\begin{array}{l}\text { Alkaline halo assay; DNA repair } \\
\text { (SB rejoining-PCR assay) }\end{array}$ & $\begin{array}{l}\text { Thymocytes from } \gamma \text {-irradiated } \\
\text { mice }\end{array}$ & $15 \mathrm{mg} / \mathrm{kg}$ (one dose, i.p.) & $\begin{array}{l}\text { Protection against } \gamma \text {-ray-induced DNA } \\
\text { SBs and accelerated rejoining }\end{array}$ \\
\hline [34] & $\begin{array}{l}\text { Cotinus coggyria } \\
\text { extract }\end{array}$ & & Comet assay on liver & Rats + pyrogallol & $0.5-2 \mathrm{~g} / \mathrm{kg}$ (single dose, i.p.) & $\begin{array}{l}\text { SBs at highest dose of extract alone: } \\
\text { protection against pyrogallol-induced SBs } \\
\text { at } 0.5 \mathrm{~g} / \mathrm{kg}\end{array}$ \\
\hline
\end{tabular}


Table 2. Cont

\begin{tabular}{|c|c|c|c|c|c|c|}
\hline Reference & Material tested & Analysis & Assays & System & Concentration/Dose & Result \\
\hline \multicolumn{7}{|c|}{ In Vitro } \\
\hline \multicolumn{7}{|c|}{ Tea-Related } \\
\hline [35] & $\begin{array}{l}\text { Green tea } \\
\text { polyphenols }\end{array}$ & & Comet assay & Melanoma cell lines & 20-60 $\mu \mathrm{g} / \mathrm{mL}$ (time) & $40,60 \mu \mathrm{g} / \mathrm{mL} ;$ DNA SBs $\uparrow$ \\
\hline [36] & Green tea extract & & Comet assay & $\begin{array}{l}\text { Human laryngeal carcinoma cell } \\
\text { line (HEp2) + drug-resistant cell } \\
\text { line CK2 }\end{array}$ & $\begin{array}{l}1 \times=2 \mathrm{~g} / 200 \mathrm{~mL} \mathrm{H}_{2} \mathrm{O}_{2} \\
\text { Concentration tested }=0.1 \times\end{array}$ & SBs $\uparrow$ at $72 \mathrm{~h}$, not $48 \mathrm{~h}$ \\
\hline \multicolumn{7}{|c|}{ Lamiaceae } \\
\hline \multirow{2}{*}{ [37] } & \multirow{2}{*}{$\begin{array}{l}\text { Citrus and rosemary } \\
\text { bioflavonoid extract }\end{array}$} & \multirow{2}{*}{ Total polyphenols } & Comet assay & $\begin{array}{l}\text { HaCaT (human keratinocytes) + } \\
\text { UV(B) }\end{array}$ & $100 \mu \mathrm{g} / \mathrm{mL}$ & Pre-treatment: UV(B)-induced DNA SBs $\downarrow$ \\
\hline & & & $\mathrm{MN}$ & Human lymphocytes $+\mathrm{X}$-ray & $1 \mathrm{mg} / \mathrm{mL}$ & X-ray induced $\mathrm{MN} \downarrow$ \\
\hline [38] & $\begin{array}{l}\text { Thymus vulgaris } \\
\text { extract }\end{array}$ & & Comet assay and $\gamma-\mathrm{H} 2 \mathrm{AX}$ by $\mathrm{Ab}$ & $\begin{array}{l}\text { Human skin model exposed to } \\
\text { UV(B) }\end{array}$ & $1.8 \mu \mathrm{g} / \mathrm{mL}$ & Protection against DNA damage \\
\hline \multirow{3}{*}{ [39] } & \multirow{3}{*}{$\begin{array}{l}\text { Thymus vulgaris } \\
\text { extract }\end{array}$} & & Comet assay $24 \mathrm{~h}$ after UV & \multirow{3}{*}{$\begin{array}{l}\text { NCTC (human keratinocytes) + } \\
\text { UV(A) or UV(B) }\end{array}$} & \multirow{3}{*}{$1.82 \mu \mathrm{g} / \mathrm{mL}$} & DNA SBs $\downarrow$ \\
\hline & & & MN & & & No effect seen \\
\hline & & & $\gamma-\mathrm{H} 2 \mathrm{AX}$ by $\mathrm{Ab}$ & & & No effect seen \\
\hline [40] & Lemon balm extract & Polyphenols & $\begin{array}{l}\text { Comet assay and } \gamma-\mathrm{H} 2 \mathrm{AX} \text { by } \mathrm{Ab} \\
\text { assay }\end{array}$ & Human keratinocytes + UV(B) & $15-100 \mu \mathrm{g} / \mathrm{mL}$ & $\begin{array}{l}\text { DNA SBs } \downarrow(100 \mu \mathrm{g} / \mathrm{mL}) ; \gamma \mathrm{H} 2 \mathrm{AX} \downarrow \\
(15 \mu \mathrm{g} / \mathrm{mL})\end{array}$ \\
\hline [41] & $\begin{array}{l}\text { Ocimum sanctum } \\
\text { extract ("Holy basil") }\end{array}$ & Total phenolics & Comet assay & $\begin{array}{l}\text { SH-SY5Y (human neuroblastoma) } \\
\text { cells }\end{array}$ & $75 \mu \mathrm{g} / \mathrm{mL}$ & $\mathrm{H}_{2} \mathrm{O}_{2}$-induced DNA SBs $\downarrow$ \\
\hline [42] & $\begin{array}{l}\text { Various Lamiaceae leaf } \\
\text { extracts }\end{array}$ & $\begin{array}{l}\text { Total polyphenols, } \\
\text { flavonoids }\end{array}$ & Comet assay & $\begin{array}{l}\text { HepG2 (human liver carcinoma) } \\
\text { cells }+\mathrm{CdCl}_{2}\end{array}$ & $50-350 \mu \mathrm{g} / \mathrm{mL}$ for $4 \mathrm{~h}$ & $\begin{array}{l}\text { Dose-dependent decrease in Cd-induced } \\
\text { DNA SBs }\end{array}$ \\
\hline \multicolumn{7}{|c|}{ Fruits and Berries } \\
\hline [43] & Strawberry extract & Anthocyanins & Comet assay & $\begin{array}{l}\text { Human dermal fibroblasts exposed } \\
\text { to UV(A) }\end{array}$ & $0.05-0.5 \mathrm{mg} / \mathrm{mL}$ & $\begin{array}{l}\text { Protection against DNA SBs at } 0.25, \\
0.5 \mathrm{mg} / \mathrm{mL}\end{array}$ \\
\hline [44] & Strawberry extract & $\begin{array}{l}\text { Total phenolics, } \\
\text { flavonoids, } \\
\text { anthocyanins, } \\
\text { vitamin } C \text {, } \\
\beta \text {-carotene }\end{array}$ & Comet assay & $\begin{array}{l}\text { Human dermal fibroblasts exposed } \\
\text { to } \mathrm{H}_{2} \mathrm{O}_{2}\end{array}$ & $0.5 \mathrm{mg} / \mathrm{mL}$ & DNA SBs $\downarrow$ \\
\hline [45] & $\begin{array}{l}\text { Vaccinium berries } \\
\text { extract }\end{array}$ & $\begin{array}{l}\text { Total polyphenols } \\
\text { and anthocyanins }\end{array}$ & Comet assay & $\begin{array}{l}\text { A549 (human lung } \\
\text { adenocarcinoma) cells }\end{array}$ & $21-167 \mu \mathrm{g} / \mathrm{mL}$ & $\begin{array}{l}\text { Dose-dependent protection against DNA } \\
\text { SBs induced by t-BOOH }\end{array}$ \\
\hline \multirow{2}{*}{ [46] } & \multirow{2}{*}{ Blackcurrant extract } & & Comet assay $\left(\mathrm{H}_{2} \mathrm{O}_{2}\right.$ resistance $)$ & \multirow{2}{*}{ TK6 (human lymphoblastoid) cells } & $0.5-3 \mathrm{mg} / \mathrm{mL}$ & $\mathrm{H}_{2} \mathrm{O}_{2}$-induced DNA SBs $\downarrow$ \\
\hline & & & $\mathrm{MN} \pm \mathrm{H}_{2} \mathrm{O}_{2}$ & & $1 \mathrm{mg} / \mathrm{mL}$ & $\mathrm{H}_{2} \mathrm{O}_{2}$-induced $\mathrm{MN} \downarrow$ \\
\hline
\end{tabular}


Table 2. Cont

\begin{tabular}{|c|c|c|c|c|c|c|}
\hline Reference & Material tested & Analysis & Assays & System & Concentration/Dose & Result \\
\hline [47] & $\begin{array}{l}\text { Various apple } \\
\text { polyphenol s } \\
\text { extract }\end{array}$ & $\begin{array}{l}\text { Monomeric } \\
\text { polyphenols } \\
\text { oligosaccharides } \\
\text { and oligomeric } \\
\text { procyanidins. }\end{array}$ & Comet assay with Fpg & Caco2 (colon carcinoma) cells & $1-100 \mu \mathrm{g} / \mathrm{mL}$ & $\begin{array}{l}\text { Menadione-induced DNA SBs and } \\
\text { Fpg-sensitive sites } \downarrow \text { Greatest protection } \\
\text { at low concentrations; with some } \\
\text { extracts, damage } \uparrow \text { at high doses }\end{array}$ \\
\hline [48] & $\begin{array}{l}\text { Polyphenol } \\
\text { extracts of } \\
\text { Australian fruits }\end{array}$ & $\begin{array}{l}\text { Phenolic acids } \\
\text { and anthocyanins }\end{array}$ & $\mathrm{MN}$ & $\begin{array}{l}\text { HT29 (human colon } \\
\text { adenocarcinoma) cells }\end{array}$ & $0.5-1 \mathrm{mg} / \mathrm{mL}$ & $\mathrm{MN} \uparrow$ with one extract \\
\hline [49] & Red wine extract & & Comet assay & $\begin{array}{l}\text { HUVECs (human umbilical vein } \\
\text { endothelial) cells }+t \text {-BOOH }\end{array}$ & $25 \mu \mathrm{g} / \mathrm{mL}$ & DNA SBs $\downarrow$ \\
\hline \multicolumn{7}{|c|}{ Honey-Related } \\
\hline \multirow{2}{*}{ [16] } & \multirow{2}{*}{ Honey extract } & \multirow{2}{*}{$\begin{array}{l}\text { Phenolic } \\
\text { compounds }\end{array}$} & Comet assay with EndoIII, Fpg & \multirow{2}{*}{$\begin{array}{l}\text { Bronchial epithelial and neuronal } \\
\text { cells }\end{array}$} & \multirow{2}{*}{$5 \mu \mathrm{g} / \mathrm{mL}$} & $\begin{array}{l}\text { Pesticide (glyphosate, } \\
\text { chlorpyrifos)-induced damage (SBs, } \\
\text { EndoIII and Fpg sites) } \downarrow\end{array}$ \\
\hline & & & Cellular DNA repair & & & $\begin{array}{l}\text { Protection against inhibition of repair of } \\
\text { DNA SBs by pesticides }\end{array}$ \\
\hline [50] & Propolis extr & & Comet assay & Fibroblasts & $0.1-0.3 \mathrm{mg} / \mathrm{mL}$ & $\gamma$-Ray-induced DNA SBs $\downarrow$ \\
\hline [51] & Propolis & & Comet assay + Fpg, EndoIII & Human gastric cancer cell line AGS & $0.3 \mu \mathrm{g} / \mathrm{mL}$ & $\begin{array}{l}\text { High DNA damage, suppressed by } \\
\text { antioxidants or catalase }\end{array}$ \\
\hline
\end{tabular}

Table 3. Effects of individual polyphenolic compounds on various genetic damage endpoints, in humans, in animals ('in vivo'), and in cultured cells ('in vitro').

\begin{tabular}{|c|c|c|c|c|c|}
\hline Reference & Material Tested & Assays & System & Concentration/Dose & Result \\
\hline \multicolumn{6}{|c|}{ In Humans } \\
\hline [52] & Epigallocatechin gallate & $\begin{array}{l}\text { 8-OH-G in leukocyte DNA } \\
\text { (HPLC/UV/MS) }\end{array}$ & Prostate cancer patients & $800 \mathrm{mg} /$ day ( 3 to 6 weeks before surgery) & Decrease in $8-\mathrm{OH}-\mathrm{G}$ not significant \\
\hline \multirow{2}{*}{ [53] } & Xanthohumol (drink) & $\begin{array}{l}\text { Comet assay and urinary 8-OH-G } \\
\text { (UPLC) }\end{array}$ & $\begin{array}{l}\text { Cross over intervention } \\
\text { trial, healthy subjects }\end{array}$ & \multirow{2}{*}{$12 \mathrm{mg} /$ day for 14 days } & FPG-sites $\downarrow, \mathrm{H}_{2} \mathrm{O}_{2}$-induced SBs $\downarrow, 8$-OH-G $\downarrow$ \\
\hline & Xanthohumol (pills) & Comet assay & $\begin{array}{l}\text { Parallel intervention trial, } \\
\text { healthy subjects }\end{array}$ & & FPG-sites $\downarrow, \mathrm{H}_{2} \mathrm{O}_{2}$-induced SBs $\downarrow$ \\
\hline \multicolumn{6}{|l|}{ In Vivo } \\
\hline \multirow{3}{*}{ [54] } & Luteolin & \multirow{3}{*}{$\begin{array}{l}\text { Comet assay and } \mathrm{MN} \text { on blood } \\
\text { and bone marrow }\end{array}$} & \multirow{3}{*}{ Mice + ochratoxin A } & $2.5 \mathrm{mg} / \mathrm{kg}$ (one dose i.p.) & No effect \\
\hline & Chlorogenic acid & & & $10 \mathrm{mg} / \mathrm{kg}$ (one dose i.p.) & DNA SBs $\downarrow ;$ also MN $\downarrow$ \\
\hline & Caffeic acid & & & $10 \mathrm{mg} / \mathrm{kg}$ (one dose i.p.) & DNA SBs $\downarrow$ \\
\hline
\end{tabular}


Table 3. Cont.

\begin{tabular}{|c|c|c|c|c|c|}
\hline Reference & Material Tested & Assays & System & Concentration/Dose & Result \\
\hline \multirow[b]{2}{*}{ [55] } & Curcumin & \multirow[b]{2}{*}{$\begin{array}{l}\text { Comet assay with FPG on } \\
\text { bone marrow }\end{array}$} & \multirow[b]{2}{*}{ Rats + etoposide } & 100 or $200 \mathrm{mg} / \mathrm{kg} /$ day (7 days, gavage) & $\begin{array}{l}\text { Pretreatment } \rightarrow \text { etoposide-induced DNA } \\
\text { damage } \downarrow\end{array}$ \\
\hline & Epicatechin & & & 20 or $40 \mathrm{mg} / \mathrm{kg} /$ day (7 days, gavage) & $\begin{array}{l}\text { Pretreatment } \rightarrow \text { etoposide-induced oxidative } \\
\text { DNA damage } \downarrow \text { (less than with Curcumin) but } \\
\text { not DNA SBs. }\end{array}$ \\
\hline$[56]$ & Ellagic acid & $\begin{array}{l}\text { MN in polychromatic erythrocytes; } \\
\text { alkaline unwinding }\end{array}$ & $\begin{array}{l}\text { Swiss albino mice }+ \\
\text { cyclophosphamide }\end{array}$ & $50 / 100 \mathrm{mg} / \mathrm{kg} /$ day (orally, 7 days) & Protection against $\mathrm{MN}$ formation and DNA SBs \\
\hline \multirow{2}{*}{ [57] } & $\begin{array}{l}\text { Epigallocatechin gallate } \\
\text { and theaflavin }\end{array}$ & \multirow{2}{*}{ Alkaline unwinding assay } & \multirow{2}{*}{$\begin{array}{l}\text { Mouse skin }+ \\
\text { dimethylbenzanthracene }\end{array}$} & 100 mg/mouse (topical application, $1 \mathrm{~h}$ ) & Topical pretreatment $\rightarrow$ DNA SBs $\downarrow$ \\
\hline & $\begin{array}{l}\text { Epigallocatechin gallate and } \\
\text { theaflavin as NPs (PLGA) }\end{array}$ & & & 5-20 $\mu \mathrm{g} /$ mouse (topical application, $1 \mathrm{~h}$ ) & NP form has $\sim 30$-fold dose-advantage \\
\hline [58] & Epigallocatechin gallate & $\begin{array}{l}\gamma-\mathrm{H} 2 \mathrm{AX} \text { by Western blot and } \mathrm{Ab} \text { and } \\
8-\mathrm{OH}-\mathrm{G} \text { by Ab assay }\end{array}$ & $\begin{array}{l}\text { H1299 (human lung cancer } \\
\text { cells) xenografts in mice }\end{array}$ & $\begin{array}{l}0.1 \%-0.5 \% \text { in diet, } 30 \mathrm{mg} / \mathrm{kg} / \text { day } \\
\text { injection }\end{array}$ & Dose-dependent $\uparrow$ in $\gamma$ - $\mathrm{H} 2 \mathrm{AX}$ and 8 -OH-G \\
\hline [59] & Silibinin & $\begin{array}{l}\text { 8-OH-G in various brain regions by } \\
\text { ELISA }\end{array}$ & Diabetic mice & $20 \mathrm{mg} / \mathrm{kg} /$ day i.p. (4 weeks) & 8-OH-G $\downarrow$ in different regions of brain \\
\hline [60] & Quercetin & $\mathrm{MN}$ in bone marrow and blood & Rats + PCBs & $50 \mathrm{mg} / \mathrm{kg} /$ day for 25 days & PCB-induced MN $\downarrow$ \\
\hline \multirow{2}{*}{ [61] } & Quercetin & \multirow{2}{*}{$\begin{array}{l}\text { Chrom abs and } \mathrm{MN} \text { in bone marrow; } \\
\text { Comet assay on blood }\end{array}$} & \multirow{2}{*}{ Mice $+\gamma$-irradiation } & $20 \mathrm{mg} / \mathrm{kg} /$ day for 5 days & \multirow{2}{*}{ Radiation-induced Chrom abs, SBs, MN $\downarrow$} \\
\hline & Rutin & & & $10 \mathrm{mg} / \mathrm{kg} /$ day for 5 days & \\
\hline [62] & Chrysin & $\begin{array}{l}\text { Comet assay (hepatocytes and } \\
\text { leukocytes) }\end{array}$ & Rats + methyl mercury & $0.1,1,10 \mathrm{mg} / \mathrm{kg} /$ day for 45 days & MeHg-induced SBs $\downarrow$ at higher doses \\
\hline [63] & Puerarin & 8-OH-G in kidney by HPLC & Mice $+\mathrm{CCl} 4$ & 0.2 or $0.4 \mathrm{~g} / \mathrm{kg} /$ day for 4 weeks & $8-\mathrm{OH}-\mathrm{G} \downarrow$ \\
\hline [64] & Quercetin & 8-OH-G in kidney by HPLC & Rats + lead & $10 \mathrm{mg} / \mathrm{kg} /$ day for 10 weeks & $8-\mathrm{OH}-\mathrm{G} \downarrow$ \\
\hline [65] & Myricitrin, Myricetin & $\begin{array}{l}\text { MN (reticulocytes); Comet assay } \\
\text { (liver, duodenum, stomach) }\end{array}$ & Mice & $1,1.5,2 \mathrm{~g} / \mathrm{kg} /$ day for 3 days & No increase in MN, SBs only in liver + myricetin \\
\hline [66] & Quercetin & Comet assay on liver & Rats + DEN & $10,30,100 \mathrm{mg} / \mathrm{kg} /$ day for 5 days & DEN-induced SBs $\downarrow$ \\
\hline [34] & Myricetin & Comet assay on liver & Rats + pyrogallol & $255.5 \mu \mathrm{g} / \mathrm{kg} 2 \mathrm{~h}$ and $12 \mathrm{~h}$ before pyrogallol & SBs $\downarrow$ in liver \\
\hline \multirow[b]{2}{*}{ [67] } & \multirow[b]{2}{*}{ Quercitin } & Comet assay on liver & \multirow{2}{*}{ Rats + acrylamide } & \multirow{2}{*}{$10 \mathrm{mg} / \mathrm{kg} /$ day for 5 days } & $\begin{array}{l}\text { No effect of quercetin alone. } \\
\text { Acrylamide-induced SBs } \downarrow\end{array}$ \\
\hline & & 8-OH-G in liver by ELISA & & & $\begin{array}{l}\text { No effect of quercetin alone. } \\
\text { Acrylamide-induced 8-OH-G } \downarrow\end{array}$ \\
\hline \multirow{2}{*}{ [68] } & \multirow{2}{*}{ Naringin } & \multirow{2}{*}{ Comet assay } & \multirow{2}{*}{$\begin{array}{l}\text { Mice (hepatocytes and } \\
\text { cardiocytes) }\end{array}$} & 50,250 or $500 \mathrm{mg} / \mathrm{kg}$ oral (one dose) & No effect \\
\hline & & & & $\begin{array}{l}50,250 \text { or } 500 \mathrm{mg} / \mathrm{kg} \text { oral (one dose) + } \\
\text { Dau i.p. }\end{array}$ & DNA SBs induced by Dau $\downarrow$ \\
\hline [69] & Apigenin & $\begin{array}{l}\text { Chrom abs and } \mathrm{MN} \text { in bone marrow; } \\
\text { comet assay on skin; DNA repair } \\
\text { (removal of CPDs by } \mathrm{Ab} \text { ) }\end{array}$ & Mice + UV(B) & $\begin{array}{l}1.5-3 \mathrm{mg} / \mathrm{cm}^{2} \text { ( } 24 \mathrm{~h} \text {; during UV } \\
\text { irradiation) }\end{array}$ & $\begin{array}{l}\text { Chrom abs and MN } \downarrow \text {; tail length } \downarrow \text {. Removal of } \\
\text { dimers apparently stimulated by apigenin }\end{array}$ \\
\hline
\end{tabular}


Table 3. Cont

\begin{tabular}{|c|c|c|c|c|c|}
\hline Reference & Material Tested & Assays & System & Concentration/Dose & Result \\
\hline \multicolumn{6}{|l|}{ In Vitro } \\
\hline \multicolumn{6}{|l|}{ Tea-Related } \\
\hline [70] & Chlorogenic acid & Comet assay & $\begin{array}{l}\text { HaCaT (human keratinocytes) } \\
\text { cells + UV(B) }\end{array}$ & Not stated. Probably $5-80 \mu \mathrm{M}$ & DNA SBs $\downarrow$ \\
\hline \multirow[b]{2}{*}{ [71] } & \multirow{2}{*}{ Chlorogenic acid } & Comet assay & K562 (human leukaemia) cells & $0.5-5 \mathrm{mM}$ & DNA SBs $\uparrow$ \\
\hline & & $\gamma-\mathrm{H} 2 \mathrm{AX}$ by $\mathrm{Ab}$ & $\begin{array}{l}\text { Chinese hamster AA8 cell line } \\
\text { and K562 }\end{array}$ & $0.5 \mathrm{mM}$ & $\gamma-\mathrm{H} 2 \mathrm{AX}$ foci $\uparrow$ \\
\hline [72] & $\begin{array}{l}\text { Chafuroside B } \\
\text { (tea polyphenol) }\end{array}$ & CPDs by $\mathrm{Ab}$ & Human keratinocytes + UV(B) & $1 \mu \mathrm{M}$ & CPDs $\downarrow$ after $24 \mathrm{~h}$ \\
\hline [73] & Ellagic acid & Comet assay & $\begin{array}{l}\text { Prostate cancer cell lines } \\
\text { LNCaP, DU145, BPH-1 }\end{array}$ & $4.5-300 \mu \mathrm{M}$ & $\begin{array}{l}\text { DNA SBs } \uparrow \text { at } 9 \mu \mathrm{M} \text { in BPH-1, } 37 \mu \mathrm{M} \text { in DU } 145, \\
150 \mu \mathrm{M} \text { in LnCap }\end{array}$ \\
\hline [74] & Epicatechin gallate & Comet assay; MN & C6 astroglial cells & $0.1-1 \mu \mathrm{M}$ & $\mathrm{H}_{2} \mathrm{O}_{2}$-induced DNA SBs and MN formation $\downarrow$ \\
\hline [58] & Epigallocatechin gallate & $\begin{array}{l}\gamma \text {-H2AX and } 8-\mathrm{OH}-\mathrm{G} \text { by } \mathrm{Ab} \\
\text { assay }\end{array}$ & $\begin{array}{l}\text { H1299 (human lung } \\
\text { adenocarcinoma) cells }\end{array}$ & $50 \mu \mathrm{M}$ & $\gamma-\mathrm{H} 2 \mathrm{AX}$ and $8-\mathrm{OH}-\mathrm{G} \uparrow$ \\
\hline [75] & $\begin{array}{l}\text { Metabolites of quercetin, } \\
\text { chlorogenic acid }\end{array}$ & Comet assay & $\begin{array}{l}\text { LT97 (human colorectal } \\
\text { adenoma) cells + cumene } \\
\text { hydroperoxide }\end{array}$ & $2.5 \mu \mathrm{M} / 5 \mu \mathrm{M}$ & Decrease in DNA SBs \\
\hline [76] & Epigallocatechin gallate & Comet assay & $\begin{array}{l}\text { HeLa (human cervical cancer) } \\
\text { cells, p53R (cells with } \\
\text { p53 reporter) }\end{array}$ & $10,20 \mu \mathrm{g} / \mathrm{mL}$ & DNA SBs $\uparrow$ \\
\hline [77] & Ethyl gallate & Comet assay & Human carcinoma cell line KB & $20-50 \mu \mathrm{g} / \mathrm{mL}$ & DNA SBs $\uparrow$ \\
\hline \multirow{2}{*}{ [78] } & Tannic acid & \multirow{2}{*}{ Comet assay with Fpg } & \multirow{2}{*}{ Human neutrophils } & \multirow{2}{*}{$10-150 \mu \mathrm{M}$} & $\begin{array}{l}\text { DNA SBs } \uparrow \text { (dose-dependent); weak effect }(\uparrow \text { ) in } \\
\text { TPA-stimulated cells. Fpg sites also } \uparrow \text {, but } \downarrow \text { in } \\
\text { TPA-stimulated cells }\end{array}$ \\
\hline & Resveratrol & & & & $\begin{array}{l}\text { DNA damage (SBs) } \uparrow \text { (dose-dependent); but } \downarrow \\
\text { (dose-dependent) in TPA-stimulated cells. Same } \\
\text { pattern with FPG sites }\end{array}$ \\
\hline \multirow{2}{*}{ [36] } & \multirow{2}{*}{$\begin{array}{l}\text { Epigallocatechin gallate; } \\
\text { Epicatechin gallate }\end{array}$} & \multirow{2}{*}{ Comet assay } & $\begin{array}{l}\text { HEp2 (human laryngeal } \\
\text { carcinoma cell line) }\end{array}$ & \multirow{2}{*}{$50 \mu \mathrm{M}$} & $\begin{array}{l}\text { With either ECG or EGCG, SBs } \downarrow \text { at } 48 \mathrm{~h} \\
\text { (from background); no effect at } 72 \mathrm{~h}\end{array}$ \\
\hline & & & $\begin{array}{l}\text { CK2 (drug resistant, } \\
\text { from HEp2) }\end{array}$ & & No effect at 48 or $72 \mathrm{~h}$ \\
\hline \multicolumn{6}{|l|}{ Curcumin } \\
\hline [79] & Curcumin; Ellagic acid & Comet assay & $\begin{array}{l}\text { HeLa (human cervical cancer) } \\
\text { cells }\end{array}$ & $25 \mu \mathrm{M}$ & $\begin{array}{l}\text { DNA SBs } \uparrow \text { (with both together; not } \\
\text { significant alone) }\end{array}$ \\
\hline
\end{tabular}


Table 3. Cont

\begin{tabular}{|c|c|c|c|c|c|}
\hline Reference & Material Tested & Assays & System & Concentration/Dose & Result \\
\hline \multirow{2}{*}{ [80]; } & Curcumin & \multirow{2}{*}{ Chrom abs and PCC } & \multirow{2}{*}{$\begin{array}{l}\text { Human lymphocytes, } \\
\text { with/without stimulation }\end{array}$} & $0.14-7 \mu \mathrm{M}$ & \multirow{2}{*}{$\begin{array}{l}\text { Radioprotective effects seen for both reagents in PCC assay } \\
\text { (non-cycling cells) } \\
\text { Radiosensitisation of cycling cells (chrom abs) by both reagents }\end{array}$} \\
\hline & Resveratrol & & & $2.2-220 \mu \mathrm{M}$ & \\
\hline [81] & Curcumin & 8-OH-G by Ab assay & Smooth muscle cells & up to $10 \mu \mathrm{M}$ & $8-\mathrm{OH}-\mathrm{G} \uparrow$ \\
\hline \multirow{2}{*}{ [82] } & \multirow{2}{*}{ Quercetin; Curcumin } & $\gamma-\mathrm{H} 2 \mathrm{AX}$ by Ab assay & \multirow{2}{*}{$\begin{array}{l}\text { HT1080 human } \\
\text { fibrosarcoma cell line }\end{array}$} & $\begin{array}{l}30 \text { and } 80 \mu \mathrm{M} \text { Quercetin; } 10 \text { and } 15 \\
\mu \mathrm{M} \text { Curcumin, }\end{array}$ & Significant increases in $\gamma \mathrm{H} 2 \mathrm{AX}$ \\
\hline & & MN & & $30 \mu \mathrm{M}$ Quercetin; $10 \mu \mathrm{M}$ Curcumin & Significant increases in MN. (Quercetin less effective.) \\
\hline \multirow{2}{*}{ [83] } & Soy isoflavones & \multirow{2}{*}{$\gamma-\mathrm{H} 2 \mathrm{AX}$ by Ab assay } & \multirow{2}{*}{$\begin{array}{l}\text { LNCaP (human prostate } \\
\text { cancer) cells }\end{array}$} & $10 \mu \mathrm{g} / \mathrm{mL}$ & No effect on H2AX \\
\hline & Curcumin & & & $25 \mu \mathrm{g} / \mathrm{mL}$ & $\gamma-\mathrm{H} 2 \mathrm{AX} \uparrow$ \\
\hline \multirow{2}{*}{ [84] } & Polyphenols & \multirow{2}{*}{ Comet assay } & \multirow{2}{*}{ Lymphocytes + B(a)P } & $5 \mu \mathrm{g} / \mathrm{mL}$ & DNA SBs $\downarrow$ \\
\hline & Curcumin & & & 5 and $10 \mu \mathrm{g} / \mathrm{mL}$ & DNA SBs $\downarrow$ \\
\hline [85] & Curcumin & Comet assay & $\begin{array}{l}\text { HCT-116 (human colon } \\
\text { cancer) cells }\end{array}$ & $50 \mu \mathrm{M}$ & DNA SBs $\uparrow$ \\
\hline [86] & Curcumin & Comet assay & $\begin{array}{l}\text { K562 (human } \\
\text { leukaemia) cells }\end{array}$ & $12.5-200 \mu \mathrm{M}$ & DNA SBs $\uparrow$ \\
\hline \multicolumn{6}{|l|}{ Resveratrol } \\
\hline [87] & Resveratrol & Chrom abs & $\begin{array}{l}\text { Human lymphocytes } \\
+ \text { aflatoxin }\end{array}$ & $10-100 \mu \mathrm{M}$ & $\begin{array}{l}\text { No effect of resveratrol alone. Dose-dependent decrease in } \\
\text { aflatoxin-induced chrom abs }\end{array}$ \\
\hline [89] & Resveratrol & $\gamma-\mathrm{H} 2 \mathrm{AX}$ by Ab assay & $\begin{array}{l}\text { HCT-116 (human colon } \\
\text { cancer) cells }\end{array}$ & $25 \mu \mathrm{M}$ & $\begin{array}{l}\gamma-\mathrm{H} 2 \mathrm{AX} \text { foci } \uparrow: \text { DNA damage due to toposiomerase II } \\
\text { poisoning }\end{array}$ \\
\hline [90] & Resveratrol & $\gamma-\mathrm{H} 2 \mathrm{AX}$ by Ab assay & Prostate epithelial cells & $5 \mu \mathrm{M}$ & Ionising radiation-induced damage enhanced \\
\hline [91] & Resveratrol & Comet assay & Rat astrocytes + ethanol & $1-10 \mu \mathrm{M}$ & $\downarrow$ DNA SBs induced by ethanol \\
\hline \multicolumn{6}{|l|}{ Lamiaceae } \\
\hline \multirow{3}{*}{ [39] } & \multirow{3}{*}{ Thymol } & Comet assay $24 \mathrm{~h}$ after UV & \multirow{3}{*}{$\begin{array}{l}\text { NCTC (human } \\
\text { keratinocytes) + UV(A) } \\
\text { or UV(B) }\end{array}$} & \multirow{3}{*}{$1 \mu \mathrm{g} / \mathrm{mL}$} & DNA SBs $\downarrow$ \\
\hline & & $\mathrm{MN}$ & & & No effect seen \\
\hline & & $\gamma-\mathrm{H} 2 \mathrm{AX}$ by Ab assay & & & No effect seen \\
\hline \multicolumn{6}{|l|}{ Flavonoids } \\
\hline \multirow{2}{*}{ [92] } & \multirow{2}{*}{ Naringin } & Chromosome aberrations & \multirow{2}{*}{$\begin{array}{l}\text { Human lymphocytes } \\
\text { treated with Cd }\end{array}$} & \multirow{2}{*}{$1,2 \mu \mathrm{g} / \mathrm{mL}$} & Cd-induced chrom abs $\downarrow$ \\
\hline & & SCE & & & No significant effect on SCE \\
\hline \multirow{2}{*}{ [93] } & \multirow{2}{*}{ Rutin } & Comet assay & \multirow{2}{*}{ Rat hepatic cell line HTC } & \multirow{2}{*}{$10-810 \mu \mathrm{g} / \mathrm{mL}(24 \mathrm{~h})$} & SBs at highest concentration \\
\hline & & $\mathrm{MN}$ & & & $\begin{array}{l}\text { No significant increase in MN—but protection against } \mathrm{MN} \\
\text { induced by } \mathrm{B}(\mathrm{a}) \mathrm{P}\end{array}$ \\
\hline
\end{tabular}


Table 3. Cont.

\begin{tabular}{|c|c|c|c|c|c|}
\hline Reference & Material Tested & Assays & System & Concentration/Dose & Result \\
\hline [94] & Quercetin; Rutin & ã-H2AX by Ab assay & V79 lung fibroblast hamster cells & $100 \mu \mathrm{g} / \mathrm{mL}$ for $12 \mathrm{~h}$ & Massive foci, results of lethality \\
\hline [95] & Kaempferol & Comet assay & HL-60 human leukemia cells & $75 \mu \mathrm{M}, 6-48 \mathrm{~h}$ & SBs induced \\
\hline \multirow{2}{*}{ [96] } & Quercetin & \multirow{2}{*}{ Comet assay } & \multirow{2}{*}{$\begin{array}{l}\text { Lymphocytes from healthy } \\
\text { subjects and colon cancer patients, } \\
+ \text { food mutagens PhIP and IQ }\end{array}$} & $100,250,500 \mu \mathrm{M}$ & \multirow{2}{*}{ SBs induced by PhIP or IQ $\downarrow$} \\
\hline & Rutin & & & $50,250,500 \mu \mathrm{M}$ & \\
\hline [97] & $\begin{array}{l}\text { Fisetin, Kaempferol; } \\
\text { Galangin; Quercetin; } \\
\text { Luteolin; Chrysin; } \\
\text { 7-hydroxyflavone; } \\
\text { 7,8-dihydroxyflavone; } \\
\text { Baicalein; Rutin }\end{array}$ & Comet assay; MN & $\begin{array}{l}\text { HepG2 (human liver carcinoma) } \\
\text { cells }+\mathrm{B}(\mathrm{a}) \mathrm{P}\end{array}$ & $2.5-25 \mu \mathrm{M}$ & $\begin{array}{l}\text { SBs induced by B(a)P } \downarrow \text { (all except rutin); MN } \\
\text { induced by B(a)P } \downarrow \text { (all except rutin); } \\
\text { Fi }>\mathrm{Qu}>\mathrm{Ga}>\mathrm{Ka}>\mathrm{Lu} \text { (more effective group); Ch, } \\
7 \mathrm{Fl}, 7,8 \mathrm{Fl}, \mathrm{Ba} \text { (less effective group) }\end{array}$ \\
\hline [98] & Fisetin & Comet assay & Human hepatic Huh-7 cells & $60 \mu \mathrm{M}$ & SBs $\uparrow$ \\
\hline [99] & Kaempferol & Comet assay & Human osteosarcoma cells U2-OS & $50,100,150 \mu \mathrm{M}$ & SBs $\uparrow$ (not quantitated) \\
\hline \multirow{2}{*}{ [65] } & Myricitrin & \multirow{2}{*}{$\mathrm{MN}$} & \multirow{2}{*}{ TK6 (human lymphoblastoid) cells } & $20-500 \mu \mathrm{g} / \mathrm{mL}$ for $24 \mathrm{~h}$ & $\mathrm{MN} \uparrow$ (Dose-dependent) \\
\hline & Myricetin & & & $2.5-75 \mu \mathrm{g} / \mathrm{mL}$ for $24 \mathrm{~h}$ & $\mathrm{MN} \uparrow$ (significant?) \\
\hline \multirow[b]{2}{*}{ [100] } & \multirow[b]{2}{*}{ Quercetin and rutin } & \multirow[b]{2}{*}{ Comet assay } & Human hepatoma cell line HepG2 & $0.1,1$ and $5 \mu \mathrm{g} / \mathrm{mL}$ ( $2 \mathrm{~h}$ of treatment) & No induction of SBs (quercetin and rutin alone) \\
\hline & & & HepG2 + Aflatoxin B, MMS, Dox & Pre-, co- and post-treatment & $\begin{array}{l}\text { DNA damage induced by AFB1, MMS, Dox } \downarrow \text { in } \\
\text { all treatment conditions }\end{array}$ \\
\hline \multirow[b]{2}{*}{ [101] } & \multirow[b]{2}{*}{ Quercetin } & \multirow[b]{2}{*}{ Comet assay, 8-OH-G (HPLC) } & $\begin{array}{l}\text { Human hepatoma cell line HepG2 } \\
\text { cells }\end{array}$ & $0.1,1$ and $5 \mu \mathrm{g} / \mathrm{mL}$ ( $24 \mathrm{~h}$ of treatment) & No effect \\
\hline & & & $\mathrm{HepG} 2$ cells $+\mathrm{HgCl}_{2}$ and $\mathrm{MeHg}$ & Pre-, co- and post-treatment & $\begin{array}{l}\text { DNA damage induced by } \mathrm{HgCl}_{2} \text { and } \mathrm{MeHg} \downarrow \\
\text { in pre- and co-treatment }\end{array}$ \\
\hline \multirow{2}{*}{ [102] } & \multirow{2}{*}{ Quercitrin } & \multirow{2}{*}{ Comet assay } & \multirow{2}{*}{$\begin{array}{l}\text { Mouse epidermal cell line JB6 + } \\
\text { UV(B) }\end{array}$} & 10,20 and $80 \mu \mathrm{M}, 30 \mathrm{~min}$ & No effect \\
\hline & & & & 10,20 and $80 \mu \mathrm{M}, 30 \mathrm{~min}+\mathrm{UV}(\mathrm{B})$ & UV(B)-induced SBs $\downarrow$ \\
\hline [51] & Galangin, chrysin & Comet assay + FPG, EndoIII & $\begin{array}{l}\text { AGS human gastric } \\
\text { adenocarcinoma cells }\end{array}$ & $20 \mu \mathrm{M}(1 \mathrm{~h})$ & Base oxidation $\uparrow$ \\
\hline [69] & Apigenin & Comet assay: Chrom abs; MN & $\begin{array}{l}\text { HaCaT human keratinocytes + } \\
\text { UV(B) }\end{array}$ & $15-25 \mu \mathrm{g} / \mathrm{mL}$ & DNA damage $\downarrow$, Chrom abs $\downarrow, \mathrm{MN} \downarrow$ \\
\hline
\end{tabular}

PCB: polychlorinated biphenyls; chrom ab: chromosome aberration; DEN: diethylnitrosamine; Dau: Daunorubicin; TPA: tetradecanoyl phorbol acetate; ECG: epicatechin gallate; EGCG: epigallocatechin gallate; PCC: premature chromosome condensation; SCE: sister chromatid exchange; IQ: 2-amino-3-methylimidazo[4,5-f]quinolone; MMS: methylmethanesulphonate; AFB1: aflatoxin B1. 


\section{Results}

\subsection{Whole Foods and Drinks}

Relatively few investigations of effects of whole foods on genetic damage endpoints have been published. A variety of fruit-derived drinks as well as tea (though this could be considered an extract), and dark chocolate, were tested in human supplementation trials. A decrease in urinary 8-OH-G was seen in overweight or obese adults supplemented with orange juice [10] but levels of plasma 8-OH-G in triathletes were too low to see any effect of Aronia-citrus juice [11]. De-alcoholised wine given daily for one month was without effect on DNA SBs or Fpg-sites in peripheral blood mononuclear (PBMN) cells of post-menopausal women [13]. However, a daily blueberry drink taken for 6 weeks protected PBMN cells from $\mathrm{H}_{2} \mathrm{O}_{2}$-induced damage, but had no effect on SBs or DNA repair capacity [14]. Malhomme de la Roche et al. [15] found that ingestion of green tea protected PBMN cells challenged ex vivo with UV(A)/VIS (ultraviolet(A)/visible) radiation, but only in some subjects, described as responders. Alleva et al. [16] gave a honey supplement to humans exposed to pesticides, and found, after two weeks' supplementation, lower levels of EndoIII- and Fpg-sensitive sites in lymphocytes as well as an enhanced capacity for DNA repair. Dark chocolate induced a transient protection against $\mathrm{H}_{2} \mathrm{O}_{2}$-induced DNA damage in PBMN cells ex vivo [12].

Most of the animal studies have looked at the possible protection afforded by polyphenol-rich foods or drinks against DNA damage induced by treating the animals (rats or mice) with known carcinogens such as doxorubicin (Dox), n-nitrosodiethylamine, or sodium arsenite. Protection was claimed with Chrysobalanus icaco fruit [17], Piquia pulp [19], Açai pulp [20], and tea [18,22]; but cloudy apple juice actually increased SBs and had no effect on nitrosamine-induced damage [21]. Treatment of hyperlipidemic rats with spinach increased the resistance of blood cells ex vivo to $\mathrm{H}_{2} \mathrm{O}_{2}$-induced damage [23].

Experiments with cultured cells and whole foods/drinks are understandably rarely performed. Incubation of PBMN cells with green tea decreased DNA damage at low concentrations but increased it at the highest concentration tested (representing $71 \mathrm{mM}$ catechins) [24]. Various honeys afforded slight protection of HepG2 cells against SBs produced by treatment with certain organic carcinogens [26]. A Chinese herbal preparation caused SBs in mouse lymphoma cells and rat fibroblasts, but at extreme concentrations (1-13 mg/mL) [25].

\subsection{Extracts of Plants}

\subsubsection{Tea-Related Extracts}

One human trial and several animal experiments have been reported with tea-related extracts. Post-menopausal women with osteoporosis were supplemented with green tea polyphenols for 6 months; the level of urinary 8-OH-G decreased [27]. Xu et al. [28] found a decrease in 8-OH-G in rats given a very high dose of green tea polyphenols. Protective effects of green tea extracts against genetic damage were reported by Garcia-Rodriguez et al. [30] in mice treated with $\mathrm{Cr}(\mathrm{IV})$; and by Pu et al. [31] in rats treated with acrylonitrile. Katiyar et al. [29] found that green tea polyphenols promoted the repair of UV-induced DNA lesions in mice proficient in nucleotide excision repair (NER), but not in NER- mice. Two studies with cultured cells have found increases in DNA SBs induced by green tea extract; Prasad et al. [35] in melanoma cell lines (though at rather high concentrations), and Durgo et al. [36] in a human laryngeal carcinoma cell line.

\subsubsection{Lamiaceae Family Plants}

The Lamiaceae family includes many plants used as culinary herbs, and so they have been grouped together here. All publications in our search deal with effects in cell culture.

Calo et al. [39] tested an extract of Thymus vulgaris (and thymol in parallel) on keratinocytes irradiated with $\mathrm{UV}(\mathrm{A})$ or UV(B); they found a decrease in SBs, though no effect on MN or $\gamma-\mathrm{H} 2 \mathrm{AX}$ 
foci. A similar protective effect was reported by Cornaghi et al. [38] in a human skin model exposed to UV(B). A citrus and rosemary extract (but at high concentrations) decreased the frequency of MN induced by X-rays in human lymphocytes, and decreased UV(B)-induced SBs in keratinocytes [37]. This last group also tested lemon balm extract on UV(B)-irradiated keratinocytes and found a decrease in SBs (at a high concentration) and in $\gamma-\mathrm{H} 2 \mathrm{AX}$ foci at a more moderate concentration [40]. Thirugnanasampandan et al. [42] studied three Lamiaceae species; HepG2 cells were incubated for $4 \mathrm{~h}$ with an extract before treating with $\mathrm{CdCl}_{2}$. Dose-dependent decreases in SBs were seen with all three (though even the lowest concentration tested was high). An extract of Ocimum sanctum (a form of basil) was tested by Venuprasad et al. [41] on human neuroblastoma cells; it protected against $\mathrm{H}_{2} \mathrm{O}_{2}$-induced SBs (at a high concentration).

\subsubsection{Honey-Related Extracts}

In parallel experiments to their human honey trial, Alleva et al. [16] showed that pre-treatment of cells with honey extract protected against pesticide-induced DNA damage and inhibition of DNA repair. Propolis extract (at high concentration) decreased the frequency of $\gamma$-ray-induced SBs in fibroblasts [50], and yet-at a much lower concentration-it caused oxidative damage (SBs measured with Fpg and EndoIII together in the comet assay) in a human cancer cell line, which was suppressed by antioxidants or catalase and so was imputed to the production of $\mathrm{H}_{2} \mathrm{O}_{2}$ [51].

\subsubsection{Fruits and Berries}

All papers on extracts of fruits and berries reviewed here describe cell culture experiments and with one exception they have made use of high to extremely high extract concentrations. The extract of one Australian fruit (among several studied) caused an increase in MN [48]. Other reports are of protection against oxidation damage caused by $\mathrm{H}_{2} \mathrm{O}_{2}$ [43,44,46]; or tert-butyl-hydroperoxide (t-BOOH) [45,49]. The exception to usage of high doses is a report by Bellion et al. [47] with apple polyphenol extracts; they found that $24 \mathrm{~h}$ pre-incubation of Caco2 cells decreased the DNA damage induced by menadione (low concentrations actually giving the greatest protection).

\subsubsection{Miscellaneous Plant Extracts}

Animal experiments with various plant extracts have shown protection against SB production in liver cells of pyrogallol-treated rats (at very high doses of extract) [34]; accelerated rejoining of $\gamma$-ray-induced DNA SBs [33]; and a decrease in pyrimidine dimers in the skin of UV(B)-irradiated mice [32].

\section{Isolated Phytochemicals}

\subsection{Compounds Related to Tea and Coffee}

Compounds tested-caffeic acid, chafuroside B, chlorogenic acid, ellagic acid, epicatechin, epicatechin gallate, epigallocatechin gallate, theaflavin.

One human trial with epigallocatechin gallate in prostate cancer patients showed no significant effect on 8-OH-G in leukocytes [52]. Animal studies with single polyphenols have generally involved treating mice or rats with a known DNA-damaging agent and looking for protection against DNA breaks, MN and chrom abs. Generally, protection is seen [54,57] though in some cases at rather high doses [56,63]. Pretreatment of rats with epicatechin reduced the level of DNA breaks induced in bone marrow cells by the topoisomerase poison etoposide [55]. High concentrations have also been used in in vitro experiments with cultured cells, and have given increases in SBs and $\gamma-\mathrm{H} 2 \mathrm{AX}$ foci [71] and in $\gamma-\mathrm{H} 2 \mathrm{AX}$ and 8-OH-G [58]. Kumar et al. [79] found that a combination of ellagic acid with curcumin ( $25 \mu \mathrm{M}$ each) caused SBs while the separate compounds had no significant effect. A decrease in (background) SBs with epigallocatechin gallate or epicatechin gallate was reported by Durgo et al. [36] at 48 but not $72 \mathrm{~h}$. At more reasonable concentrations, the results are mixed: decreases 
in UV(B)-induced SBs [70] and cyclobutane pyrimidine dimers [72]; decreases in $\mathrm{H}_{2} \mathrm{O}_{2}$-induced SBs and $\mathrm{MN}$ [74]; a decrease in SBs induced by cumene hydroperoxide [75]; but SBs and Fpg-sites increased in tetradecanoyl phorbol acetate (TPA)-stimulated neutrophils [78] and an increase in SBs with ellagic acid in prostate cancer cells was reported by Vanella et al. [73] at concentrations of $9 \mu \mathrm{M}$ in one of the cell lines but higher concentrations in two other lines.

\subsection{Curcumin}

Curcumin was examined alongside epicatechin by Papiez [55]; at high concentration (up to $0.2 \mathrm{~g} / \mathrm{kg} /$ day), it decreased DNA damage in the bone marrow of rats treated with etoposide. In cultured cells, curcumin at rather high concentrations caused SBs [85,86] and $\gamma$-H2AX foci [83]. The production of SBs in combination with ellagic acid was noted above [79]. Lewinska et al. [81] reported a pro-oxidant effect of curcumin at concentrations of $10 \mu \mathrm{M}$ (and below), indicated by an increase in 8-oxo-G in smooth muscle cells. Sebastia et al. [80] compared effects of curcumin on human lymphocytes, both stimulated by TPA and unstimulated, and $\gamma$-irradiated. In non-cycling cells, the phytochemical was radioprotective (decreasing the level of premature chromosome condensation), whereas in cycling cells it acted as a radiosensitiser, increasing the frequency of chrom abs.

\subsection{Resveratrol}

At high concentration, in human lymphocytes, resveratrol decreased the frequency of chromosome aberrations caused by aflatoxin [87]. At a lower concentration, it protected human epithelial cells against SBs and MN induced by sodium arsenite [88], and rat astrocytes against SBs caused by ethanol [91]. However, a low dose enhanced the frequency of $\gamma$-H2AX foci after ionising irradiation of prostate epithelial cells [90]. A moderately high concentration applied to colon cancer cells caused $\gamma$-H2AX foci, apparently as a result of topoisomerase II poisoning [89]. SBs as well as Fpg-sites were increased in non-cycling cells but decreased in TPA-stimulated, cycling cells [78]. In contrast, Sebastia et al. [80] found that, as with curcumin, effects of resveratrol on irradiated lymphocytes differed depending on whether the cells were non-cycling (showing a decrease in premature chromosome condensation), or cycling (in which it had the opposite effect, acting as a radiosensitiser, increasing chromosome aberrations).

\subsection{Flavonoids}

Kozics et al. [97] performed a useful comparative study of 10 flavonoids, concluding that their effectiveness at protecting against B(a)P-induced SBs and MN depended on their chemical structure. Tested over a relatively low concentration range, fisetin, quercetin, galangin, kaempferol and luteolin (in order of decreasing effectiveness) were more effective than chrysin,7-hydroxyflavone, 7,8-dihydroxyflavone or baicalein, while rutin was without effect.

Among the flavonoids, quercetin appears most often in this survey. At low concentrations, SBs induced by aflatoxin B1 (AFB1), methyl methanesulphonate (MMS), Dox, $\mathrm{HgCl}_{2}$ or methyl mercury in HepG2 cells were decreased [100,101]. At high concentrations, quercetin and also rutin (glycoside of quercetin with rutinose) caused massive $\gamma-\mathrm{H} 2 \mathrm{AX}$ foci, probably reflecting lethality [94], and yet they decreased DNA damage (SBs) induced by food mutagens PhIP and IQ [96].

Quercitrin, the rhamnose glycoside of quercetin, protected mouse epidermal cells against UV(B)-induced SBs [102]. Rutin at low concentrations showed the same protective effect as quercetin on HepG2 cells treated with AFB1, MMS or Dox [100]; at much higher concentrations, it caused SBs, but still protected against MN induced by B(a)P [93].

The myricetin rhamnoside, myricitrin, at high concentrations, induced MN in TK6 cells; the aglycone myricetin, being more cytotoxic, was tested at lower concentrations, and gave equivocal results [65]. Kaempferol at high concentrations induced SBs [95,99], as did fisetin [98]. Galangin and chrysin caused base oxidation at the moderate concentration of $20 \mu \mathrm{M}$ [51], while a low concentration 
of naringin was protective against cadmium-induced chromosome aberrations [92]. Apigenin at a high concentration decreased SBs, chrom abs and MN [69].

\section{Discussion and Conclusions}

Many of the papers that we have reviewed report experiments with high or very high concentrations of phytochemicals. When investigating the role of phytochemicals in normal human nutrition, the aim should always be to study concentrations close to those likely to be present in humans as a result of dietary intake. As a rule of thumb, we have assumed this concentration to be in the low micromolar range. Many papers quote concentrations in $\mu \mathrm{g} / \mathrm{mL}$. To convert these concentrations to micromolar, again as a rule of thumb, we have assumed a molecular weight of 500; then $1 \mu \mathrm{g} / \mathrm{mL}=2 \mu \mathrm{M}$. We would regard a concentration of over $20 \mu \mathrm{M}$ or $10 \mu \mathrm{g} / \mathrm{mL}$ as high, and over $50 \mu \mathrm{M}$ or $25 \mu \mathrm{g} / \mathrm{mL}$ as very high. Clearly, in functional foods or phytochemical supplements, the concentration is likely to be higher than in natural foods, and experiments showing genotoxicity of phytochemicals at high doses should at least serve as a warning to designers of functional foods.

It is always instructive to carry out experiments over a range of concentrations. Often, in the case of micronutrients in general, the dose-response curve is U-shaped, i.e., a beneficial effect at low concentrations changes to a detrimental effect at higher concentrations, and this tendency is clear in many of the reports described here.

Of course, if genotoxicity is specifically directed to cancer cells while healthy cells are unaffected, it is regarded as beneficial, and it is evidently the aim of some of the papers that we have reviewed to identify plant extracts or particular polyphenols that have such targeted action and so might have potential value as therapeutic agents. The differential response of cycling vs non-cycling cells to certain polyphenols might be exploited therapeutically in targeting dividing cancer cells.

With such a wide-ranging set of phytochemicals, not to mention the variety of test systems, experimental designs and assays applied in their study, it is difficult to generalise. However, high concentrations are likely to show DNA-damaging effects, while also in many cases protecting cells against damaging effects of other agents, apparently acting as pro-oxidants when present alone, but as anti-oxidants in combination. This is not a novel observation: many years ago, Duthie et al. reported DNA-damaging effects of quercetin at $50 \mu \mathrm{M}$ [103] alongside an ability to protect cells against $\mathrm{H}_{2} \mathrm{O}_{2}$-induced DNA damage at concentrations of 10-50 $\mu \mathrm{M}$ [104]. Low concentrations are generally protective, in some cases even decreasing the already low background level of cellular DNA damage.

To summarise, results reported in the recent literature, on the whole, lend support to the hypothesis that dietary polyphenols protect the body against the effects of reactive oxygen species on DNA integrity, but do so reliably only when present at low concentrations. We recommend that greater attention be paid to the concentrations used, particularly in in vitro experiments, if the results are to be extrapolated to issues of human health. An important consideration when extrapolating is that plant foods contain a variety of micronutrients which might be expected to act in concert, whereas most experiments are carried out with single compounds. In this respect, there are clear advantages in using plant extracts or whole foods, though this approach does present practical difficulties. We also recommend that, since oxidative damage to DNA, and its prevention, are of major concern, the modified comet assay incorporating Fpg or EndoIII should be employed, since it provides increased sensitivity and specificity.

Acknowledgments: A.A. thanks the Ministerio de Economía y Competitividad ('Ramón y Cajal' programme, RYC-2013-14370) of the Spanish Government for personal support. This work was also supported by the BIOGENSA project (AGL2015-70640-R) of the 'Ministerio de Economía y Competitividad' of the Spanish Government.

Conflicts of Interest: The authors declare no conflict of interest. 


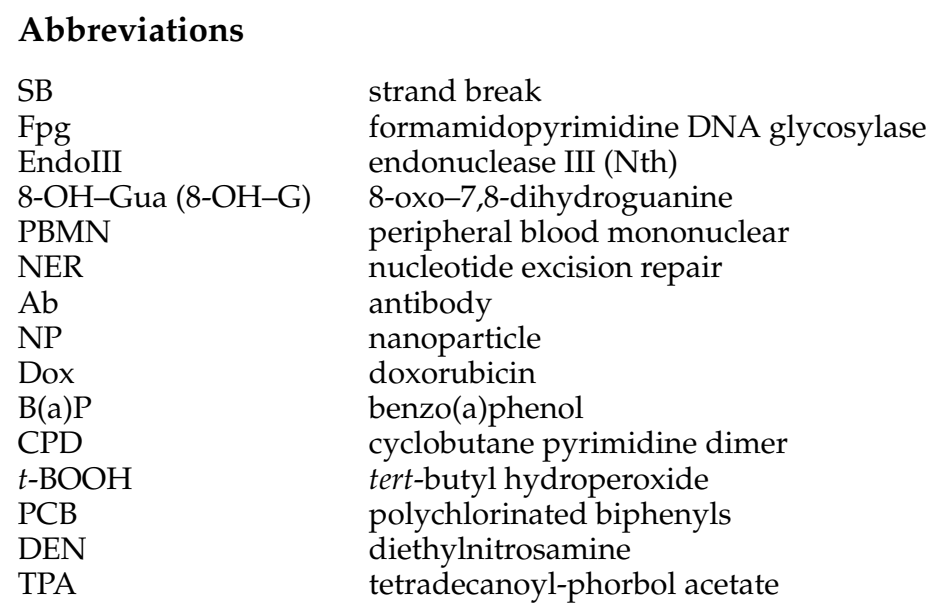

\section{References}

1. Bjelakovic, G.; Nikolova, D.; Gluud, L.L.; Simonetti, R.G.; Gluud, C. Mortality in randomized trials of antioxidant supplements for primary and secondary prevention: Systematic review and meta-analysis. J. Am. Med. Assoc. 2007, 297, 842-857. [CrossRef] [PubMed]

2. Azqueta, A.; Collins, A.R. The essential comet assay: A comprehensive guide to measuring DNA damage and repair. Arch. Toxicol. 2013, 87, 949-968. [CrossRef] [PubMed]

3. Kasai, H. Analysis of a form of oxidative DNA damage, 8-hydroxy-2'-deoxyguanosine, as a marker of cellular oxidative stress during carcinogenesis. Mutat. Res./Rev. Mutat. Res. 1997, 387, 147-163. [CrossRef]

4. Kasai, H.; Kawai, K. 8-hydroxyguanine, an oxidative DNA and RNA modification. In Modified Nucleic Acids in Biology and Medicine; Jurga, S.E., Erdmann, V.A., Barciszewski, J., Eds.; Springer: Basel, Switzerland, 2016; pp. 147-185.

5. Sedelnikova, O.A.; Rogakou, E.P.; Panyutin, I.G.; Bonner, W.M. Quantitative detection of (125)idu-induced DNA double-strand breaks with gamma-h2ax antibody. Radiat. Res. 2002, 158, 486-492. [CrossRef]

6. Huang, X.; Darzynkiewicz, Z. Cytometric assessment of histone h2ax phosphorylation: A reporter of DNA damage. Methods Mol. Biol. 2006, 314, 73-80. [PubMed]

7. Fenech, M. Cytokinesis-block micronucleus cytome assay. Nat. Protoc. 2007, 2, 1084-1104. [CrossRef] [PubMed]

8. Bonassi, S.; Norppa, H.; Ceppi, M.; Stromberg, U.; Vermeulen, R.; Znaor, A.; Cebulska-Wasilewska, A.; Fabianova, E.; Fucic, A.; Gundy, S.; et al. Chromosomal aberration frequency in lymphocytes predicts the risk of cancer: Results from a pooled cohort study of 22,358 subjects in 11 countries. Carcinogenesis 2008, 29, 1178-1183. [CrossRef] [PubMed]

9. Bonassi, S.; El-Zein, R.; Bolognesi, C.; Fenech, M. Micronuclei frequency in peripheral blood lymphocytes and cancer risk: Evidence from human studies. Mutagenesis 2011, 26, 93-100. [CrossRef] [PubMed]

10. Rangel-Huerta, O.D.; Aguilera, C.M.; Martin, M.V.; Soto, M.J.; Rico, M.C.; Vallejo, F.; Tomas-Barberan, F.; Perez-de-la-Cruz, A.J.; Gil, A.; Mesa, M.D. Normal or high polyphenol concentration in orange juice affects antioxidant activity, blood pressure, and body weight in obese or overweight adults. J. Nutr. 2015, 145, 1808-1816. [CrossRef] [PubMed]

11. Garcia-Flores, L.A.; Medina, S.; Cejuela-Anta, R.; Martinez-Sanz, J.M.; Abellan, A.; Genieser, H.G.; Ferreres, F.; Gil-Izquierdo, A. DNA catabolites in triathletes: Effects of supplementation with an aronia-citrus juice (polyphenols-rich juice). Food Funct. 2016, 7, 2084-2093. [CrossRef] [PubMed]

12. Spadafranca, A.; Martinez Conesa, C.; Sirini, S.; Testolin, G. Effect of dark chocolate on plasma epicatechin levels, DNA resistance to oxidative stress and total antioxidant activity in healthy subjects. Br. J. Nutr. 2010, 103, 1008-1014. [CrossRef] [PubMed]

13. Giovannelli, L.; Pitozzi, V.; Luceri, C.; Giannini, L.; Toti, S.; Salvini, S.; Sera, F.; Souquet, J.M.; Cheynier, V.; Sofi, F.; et al. Effects of de-alcoholised wines with different polyphenol content on DNA oxidative damage, gene expression of peripheral lymphocytes, and haemorheology: An intervention study in post-menopausal women. Eur. J. Nutr. 2011, 50, 19-29. [CrossRef] [PubMed] 
14. Riso, P.; Klimis-Zacas, D.; Del Bo, C.; Martini, D.; Campolo, J.; Vendrame, S.; Moller, P.; Loft, S.; De Maria, R.; Porrini, M. Effect of a wild blueberry (vaccinium angustifolium) drink intervention on markers of oxidative stress, inflammation and endothelial function in humans with cardiovascular risk factors. Eur. J. Nutr. 2013, 52, 949-961. [CrossRef] [PubMed]

15. Malhomme de la Roche, H.; Seagrove, S.; Mehta, A.; Divekar, P.; Campbell, S.; Curnow, A. Using natural dietary sources of antioxidants to protect against ultraviolet and visible radiation-induced DNA damage: An investigation of human green tea ingestion. J. Photochem. Photobiol. B Biol. 2010, 101, 169-173. [CrossRef] [PubMed]

16. Alleva, R.; Manzella, N.; Gaetani, S.; Ciarapica, V.; Bracci, M.; Caboni, M.F.; Pasini, F.; Monaco, F.; Amati, M.; Borghi, B.; et al. Organic honey supplementation reverses pesticide-induced genotoxicity by modulating dna damage response. Mol. Nutr. Food Res. 2016, 60, 2243-2255. [CrossRef] [PubMed]

17. Venancio, V.P.; Marques, M.C.; Almeida, M.R.; Mariutti, L.R.; Souza, V.C.; Barbosa, F., Jr.; Pires Bianchi, M.L.; Marzocchi-Machado, C.M.; Mercadante, A.Z.; Antunes, L.M. Chrysobalanus icaco 1. Fruits inhibit nadph oxidase complex and protect DNA against doxorubicin-induced damage in wistar male rats. J. Toxicol. Environ. Health Part A 2016, 79, 885-893. [CrossRef] [PubMed]

18. Sinha, D.; Roy, M. Antagonistic role of tea against sodium arsenite-induced oxidative DNA damage and inhibition of DNA repair in swiss albino mice. J. Environ. Pathol. Toxicol. Oncol. 2011, 30, 311-322. [CrossRef] [PubMed]

19. Almeida, M.R.; Darin, J.D.; Hernandes, L.C.; Aissa, A.F.; Chiste, R.C.; Mercadante, A.Z.; Antunes, L.M.; Bianchi, M.L. Antigenotoxic effects of piquia (caryocar villosum) in multiple rat organs. Plant Foods Hum. Nutr. 2012, 67, 171-177. [CrossRef] [PubMed]

20. Ribeiro, J.C.; Antunes, L.M.; Aissa, A.F.; Darin, J.D.; De Rosso, V.V.; Mercadante, A.Z.; Bianchi Mde, L. Evaluation of the genotoxic and antigenotoxic effects after acute and subacute treatments with acai pulp (euterpe oleracea mart.) on mice using the erythrocytes micronucleus test and the comet assay. Mutat. Res. 2010, 695, 22-28. [CrossRef] [PubMed]

21. Krajka-Kuzniak, V.; Szaefer, H.; Ignatowicz, E.; Adamska, T.; Markowski, J.; Baer-Dubowska, W. Influence of cloudy apple juice on n-nitrosodiethylamine- induced liver injury and phases i and ii biotransformation enzymes in rat liver. Acta Pol. Pharm. 2015, 72, 267-276. [PubMed]

22. Acharyya, N.; Sajed Ali, S.; Deb, B.; Chattopadhyay, S.; Maiti, S. Green tea (camellia sinensis) alleviates arsenic-induced damages to DNA and intestinal tissues in rat and in situ intestinal loop by reinforcing antioxidant system. Environ. Toxicol. 2015, 30, 1033-1044. [CrossRef] [PubMed]

23. Ko, S.H.; Park, J.H.; Kim, S.Y.; Lee, S.W.; Chun, S.S.; Park, E. Antioxidant effects of spinach (Spinacia oleracea L.) supplementation in hyperlipidemic rats. Prev. Nutr. Food Sci. 2014, 19, 19-26. [CrossRef] [PubMed]

24. Ho, C.K.; Siu-wai, C.; Siu, P.M.; Benzie, I.F. Genoprotection and genotoxicity of green tea (camellia sinensis): Are they two sides of the same redox coin? Redox Rep. Commun. Free Radic. Res. 2013, 18, 150-154. [CrossRef] [PubMed]

25. Kuhnel, H.; Adilijiang, A.; Dadak, A.; Wieser, M.; Upur, H.; Stolze, K.; Grillari, J.; Strasser, A. Investigations into cytotoxic effects of the herbal preparation abnormal savda munziq. Chin. J. Integr. Med. 2015, 53, 1-9. [CrossRef] [PubMed]

26. Haza, A.I.; Morales, P. Spanish honeys protect against food mutagen-induced DNA damage. J. Sci. Food Agric. 2013, 93, 2995-3000. [CrossRef] [PubMed]

27. Qian, G.; Xue, K.; Tang, L.; Wang, F.; Song, X.; Chyu, M.C.; Pence, B.C.; Shen, C.L.; Wang, J.S. Mitigation of oxidative damage by green tea polyphenols and tai chi exercise in postmenopausal women with osteopenia. PLoS ONE 2012, 7, e48090. [CrossRef] [PubMed]

28. Xu, Y.; Zhang, J.J.; Xiong, L.; Zhang, L.; Sun, D.; Liu, H. Green tea polyphenols inhibit cognitive impairment induced by chronic cerebral hypoperfusion via modulating oxidative stress. J. Nutr. Biochem. 2010, 21, 741-748. [PubMed]

29. Katiyar, S.K.; Vaid, M.; van Steeg, H.; Meeran, S.M. Green tea polyphenols prevent uv-induced immunosuppression by rapid repair of DNA damage and enhancement of nucleotide excision repair genes. Cancer Prev. Res. 2010, 3, 179-189. [CrossRef] [PubMed] 
30. Garcia-Rodriguez Mdel, C.; Carvente-Juarez, M.M.; Altamirano-Lozano, M.A. Antigenotoxic and apoptotic activity of green tea polyphenol extracts on hexavalent chromium-induced DNA damage in peripheral blood of cd-1 mice: Analysis with differential acridine orange/ethidium bromide staining. Oxidative Med. Cell. Longev. 2013, 2013, 486419. [CrossRef] [PubMed]

31. Pu, X.; Wang, Z.; Zhou, S.; Klaunig, J.E. Protective effects of antioxidants on acrylonitrile-induced oxidative stress in female f344 rats. Environ. Toxicol. 2015. [CrossRef] [PubMed]

32. Olteanu, E.D.; Filip, A.; Clichici, S.; Daicoviciu, D.; Achim, M.; Postescu, I.D.; Bolfa, P.; Bolojan, L.; Vlase, L.; Muresan, A. Photochemoprotective effect of calluna vulgaris extract on skin exposed to multiple doses of ultraviolet b in skh-1 hairless mice. J. Environ. Pathol. Toxicol. Oncol. 2012, 31, 233-243. [CrossRef] [PubMed]

33. Chaudhary, P.; Shukla, S.K.; Sharma, R.K. Rec-2006-a fractionated extract of podophyllum hexandrum protects cellular DNA from radiation-induced damage by reducing the initial damage and enhancing its repair in vivo. Evid.-Based Complement. Altern. Med. 2011, 2011, 473953. [CrossRef] [PubMed]

34. Matic, S.; Stanic, S.; Bogojevic, D.; Vidakovic, M.; Grdovic, N.; Dinic, S.; Solujic, S.; Mladenovic, M.; Stankovic, N.; Mihailovic, M. Methanol extract from the stem of cotinus coggygria scop., and its major bioactive phytochemical constituent myricetin modulate pyrogallol-induced DNA damage and liver injury. Mutat. Res. 2013, 755, 81-89. [CrossRef] [PubMed]

35. Prasad, R.; Katiyar, S.K. Polyphenols from green tea inhibit the growth of melanoma cells through inhibition of class i histone deacetylases and induction of DNA damage. Genes Cancer 2015, 6, 49-61. [PubMed]

36. Durgo, K.; Kostic, S.; Gradiski, K.; Komes, D.; Osmak, M.; Franekic, J. Genotoxic effects of green tea extract on human laryngeal carcinoma cells in vitro. Arch. Hig. Rada Toksikol. 2011, 62, 139-146. [CrossRef] [PubMed]

37. Perez-Sanchez, A.; Barrajon-Catalan, E.; Caturla, N.; Castillo, J.; Benavente-Garcia, O.; Alcaraz, M.; Micol, V. Protective effects of citrus and rosemary extracts on uv-induced damage in skin cell model and human volunteers. J. Photochem. Photobiol. B Biol. 2014, 136, 12-18. [CrossRef] [PubMed]

38. Cornaghi, L.; Arnaboldi, F.; Calo, R.; Landoni, F.; Baruffaldi Preis, W.F.; Marabini, L.; Donetti, E. Effects of uv rays and thymol/thymus vulgaris 1 . Extract in an ex vivo human skin model: Morphological and genotoxicological assessment. Cells Tissues Organs 2016, 201, 180-192. [CrossRef] [PubMed]

39. Calo, R.; Visone, C.M.; Marabini, L. Thymol and thymus vulgaris L. Activity against uva- and uvb-induced damage in nctc 2544 cell line. Mutat. Res. Genet. Toxicol. Environ. Mutagen. 2015, 791, 30-37. [CrossRef] [PubMed]

40. Perez-Sanchez, A.; Barrajon-Catalan, E.; Herranz-Lopez, M.; Castillo, J.; Micol, V. Lemon balm extract (Melissa officinalis L.) promotes melanogenesis and prevents uvb-induced oxidative stress and DNA damage in a skin cell model. J. Dermatol. Sci. 2016, 84, 169-177. [CrossRef] [PubMed]

41. Venuprasad, M.P.; Hemanth Kumar, K.; Khanum, F. Neuroprotective effects of hydroalcoholic extract of ocimum sanctum against $\mathrm{h} 2 \mathrm{o} 2$ induced neuronal cell damage in sh-sy5y cells via its antioxidative defence mechanism. Neurochem. Res. 2013, 38, 2190-2200. [CrossRef] [PubMed]

42. Thirugnanasampandan, R.; Jayakumar, R. Protection of cadmium chloride induced DNA damage by lamiaceae plants. Asian Pac. J. Trop. Biomed. 2011, 1, 391-394. [CrossRef]

43. Giampieri, F.; Alvarez-Suarez, J.M.; Tulipani, S.; Gonzales-Paramas, A.M.; Santos-Buelga, C.; Bompadre, S.; Quiles, J.L.; Mezzetti, B.; Battino, M. Photoprotective potential of strawberry (fragaria x ananassa) extract against uv-a irradiation damage on human fibroblasts. J. Agric. Food Chem. 2012, 60, 2322-2327. [CrossRef] [PubMed]

44. Giampieri, F.; Alvarez-Suarez, J.M.; Mazzoni, L.; Forbes-Hernandez, T.Y.; Gasparrini, M.; Gonzalez-Paramas, A.M.; Santos-Buelga, C.; Quiles, J.L.; Bompadre, S.; Mezzetti, B.; et al. Polyphenol-rich strawberry extract protects human dermal fibroblasts against hydrogen peroxide oxidative damage and improves mitochondrial functionality. Molecules 2014, 19, 7798-7816. [CrossRef] [PubMed]

45. Braga, P.C.; Antonacci, R.; Wang, Y.Y.; Lattuada, N.; Dal Sasso, M.; Marabini, L.; Fibiani, M.; Lo Scalzo, R. Comparative antioxidant activity of cultivated and wild vaccinium species investigated by epr, human neutrophil burst and comet assay. Eur. Rev. Med. Pharmacol. Sci. 2013, 17, 1987-1999. [PubMed]

46. Yamamoto, A.; Nakashima, K.; Kawamorita, S.; Sugiyama, A.; Miura, M.; Kamitai, Y.; Kato, Y. Protective effects of raw and cooked blackcurrant extract on DNA damage induced by hydrogen peroxide in human lymphoblastoid cells. Pharm. Biol. 2014, 52, 782-788. [CrossRef] [PubMed] 
47. Bellion, P.; Digles, J.; Will, F.; Dietrich, H.; Baum, M.; Eisenbrand, G.; Janzowski, C. Polyphenolic apple extracts: Effects of raw material and production method on antioxidant effectiveness and reduction of DNA damage in caco-2 cells. J. Agric. Food Chem. 2010, 58, 6636-6642. [CrossRef] [PubMed]

48. Tan, A.C.; Konczak, I.; Ramzan, I.; Sze, D.M. Native australian fruit polyphenols inhibit cell viability and induce apoptosis in human cancer cell lines. Nutr. Cancer 2011, 63, 444-455. [CrossRef] [PubMed]

49. Botden, I.P.; Oeseburg, H.; Durik, M.; Leijten, F.P.; Van Vark-Van Der Zee, L.C.; Musterd-Bhaggoe, U.M.; Garrelds, I.M.; Seynhaeve, A.L.; Langendonk, J.G.; Sijbrands, E.J.; et al. Red wine extract protects against oxidative-stress-induced endothelial senescence. Clin. Sci. 2012, 123, 499-507. [CrossRef] [PubMed]

50. Yalcin, C.O.; Aliyazicioglu, Y.; Demir, S.; Turan, I.; Bahat, Z.; Misir, S.; Deger, O. Evaluation of the radioprotective effect of turkish propolis on foreskin fibroblast cells. J. Cancer Res. Ther. 2016, 12, 990-994. [PubMed]

51. Tsai, Y.C.; Wang, Y.H.; Liou, C.C.; Lin, Y.C.; Huang, H.; Liu, Y.C. Induction of oxidative DNA damage by flavonoids of propolis: Its mechanism and implication about antioxidant capacity. Chem. Res. Toxicol. 2012, 25, 191-196. [CrossRef] [PubMed]

52. Nguyen, M.M.; Ahmann, F.R.; Nagle, R.B.; Hsu, C.H.; Tangrea, J.A.; Parnes, H.L.; Sokoloff, M.H.; Gretzer, M.B.; Chow, H.H. Randomized, double-blind, placebo-controlled trial of polyphenon e in prostate cancer patients before prostatectomy: Evaluation of potential chemopreventive activities. Cancer Prev. Res. 2012, 5, 290-298. [CrossRef] [PubMed]

53. Ferk, F.; Misik, M.; Nersesyan, A.; Pichler, C.; Jager, W.; Szekeres, T.; Marculescu, R.; Poulsen, H.E.; Henriksen, T.; Bono, R.; et al. Impact of xanthohumol (a prenylated flavonoid from hops) on DNA stability and other health-related biochemical parameters: Results of human intervention trials. Mol. Nutr. Food Res. 2016, 60, 773-786. [CrossRef] [PubMed]

54. Cariddi, L.N.; Sabini, M.C.; Escobar, F.M.; Montironi, I.; Manas, F.; Iglesias, D.; Comini, L.R.; Sabini, L.I.; Dalcero, A.M. Polyphenols as possible bioprotectors against cytotoxicity and DNA damage induced by ochratoxin A. Environ. Toxicol. Pharmacol. 2015, 39, 1008-1018. [CrossRef] [PubMed]

55. Papiez, M.A. The influence of curcumin and (-)-epicatechin on the genotoxicity and myelosuppression induced by etoposide in bone marrow cells of male rats. Drug Chem. Toxicol. 2013, 36, 93-101. [CrossRef] [PubMed]

56. Rehman, M.U.; Tahir, M.; Ali, F.; Qamar, W.; Lateef, A.; Khan, R.; Quaiyoom, A.; Oday, O.H.; Sultana, S. Cyclophosphamide-induced nephrotoxicity, genotoxicity, and damage in kidney genomic DNA of swiss albino mice: The protective effect of ellagic acid. Mol. Cell. Biochem. 2012, 365, 119-127. [CrossRef] [PubMed]

57. Srivastava, A.K.; Bhatnagar, P.; Singh, M.; Mishra, S.; Kumar, P.; Shukla, Y.; Gupta, K.C. Synthesis of plga nanoparticles of tea polyphenols and their strong in vivo protective effect against chemically induced DNA damage. Int. J. Nanomed. 2013, 8, 1451-1462.

58. Li, G.X.; Chen, Y.K.; Hou, Z.; Xiao, H.; Jin, H.; Lu, G.; Lee, M.J.; Liu, B.; Guan, F.; Yang, Z.; et al. Pro-oxidative activities and dose-response relationship of (-)-epigallocatechin-3-gallate in the inhibition of lung cancer cell growth: A comparative study in vivo and in vitro. Carcinogenesis 2010, 31, 902-910. [CrossRef] [PubMed]

59. Marrazzo, G.; Bosco, P.; La Delia, F.; Scapagnini, G.; Di Giacomo, C.; Malaguarnera, M.; Galvano, F.; Nicolosi, A.; Li Volti, G. Neuroprotective effect of silibinin in diabetic mice. Neurosci. Lett. 2011, 504, 252-256. [CrossRef] [PubMed]

60. Rocha de Oliveira, C.; Ceolin, J.; Rocha de Oliveira, R.; Goncalves Schemitt, E.; Raskopf Colares, J.; De Freitas Bauermann, L.; Hilda Costabeber, I.; Morgan-Martins, M.I.; Mauriz, J.L.; Da Silva, J.; et al. Effects of quercetin on polychlorinated biphenyls-induced liver injury in rats. Nutr. Hosp. 2014, 29, 1141-1148. [PubMed]

61. Patil, S.L.; Rao, N.B.; Somashekarappa, H.M.; Rajashekhar, K.P. Antigenotoxic potential of rutin and quercetin in swiss mice exposed to gamma radiation. Biomed. J. 2014, 37, 305-313. [CrossRef] [PubMed]

62. Manzolli, E.S.; Serpeloni, J.M.; Grotto, D. Protective effects of the flavonoid chrysin against methylmercury-induced genotoxicity and alterations of antioxidant status, in vivo. Oxidative Med. Cell. Longev. 2015, 2015, 602360. [CrossRef] [PubMed]

63. Ma, J.Q.; Ding, J.; Xiao, Z.H.; Liu, C.M. Puerarin ameliorates carbon tetrachloride-induced oxidative DNA damage and inflammation in mouse kidney through erk/nrf2/are pathway. Food Chem. Toxicol. 2014, 71, 264-271. [CrossRef] [PubMed]

64. Liu, C.M.; Ma, J.Q.; Sun, Y.Z. Quercetin protects the rat kidney against oxidative stress-mediated DNA damage and apoptosis induced by lead. Environ. Toxicol. Pharmacol. 2010, 30, 264-271. [CrossRef] [PubMed] 
65. Hobbs, C.A.; Swartz, C.; Maronpot, R.; Davis, J.; Recio, L.; Koyanagi, M.; Hayashi, S.M. Genotoxicity evaluation of the flavonoid, myricitrin, and its aglycone, myricetin. Food Chem. Toxicol. 2015, 83, $283-292$. [CrossRef] [PubMed]

66. Gupta, C.; Vikram, A.; Tripathi, D.N.; Ramarao, P.; Jena, G.B. Antioxidant and antimutagenic effect of quercetin against den induced hepatotoxicity in rat. Phytother. Res. 2010, 24, 119-128. [CrossRef] [PubMed]

67. Ansar, S.; Siddiqi, N.J.; Zargar, S.; Ganaie, M.A.; Abudawood, M. Hepatoprotective effect of quercetin supplementation against acrylamide-induced DNA damage in wistar rats. BMC Complement. Altern. Med. 2016, 16, 327. [CrossRef] [PubMed]

68. Carino-Cortes, R.; Alvarez-Gonzalez, I.; Martino-Roaro, L.; Madrigal-Bujaidar, E. Effect of naringin on the DNA damage induced by daunorubicin in mouse hepatocytes and cardiocytes. Biol. Pharm. Bull. 2010, 33, 697-701. [CrossRef] [PubMed]

69. Das, S.; Das, J.; Paul, A.; Samadder, A.; Khuda-Bukhsh, A.R. Apigenin, a bioactive flavonoid from lycopodium clavatum, stimulates nucleotide excision repair genes to protect skin keratinocytes from ultraviolet b-induced reactive oxygen species and DNA damage. J. Acupunct. Meridian Stud. 2013, 6, 252-262. [CrossRef] [PubMed]

70. Cha, J.W.; Piao, M.J.; Kim, K.C.; Yao, C.W.; Zheng, J.; Kim, S.M.; Hyun, C.L.; Ahn, Y.S.; Hyun, J.W. The polyphenol chlorogenic acid attenuates uvb-mediated oxidative stress in human hacat keratinocytes. Biomol. Ther. 2014, 22, 136-142. [CrossRef] [PubMed]

71. Burgos-Moron, E.; Calderon-Montano, J.M.; Orta, M.L.; Pastor, N.; Perez-Guerrero, C.; Austin, C.; Mateos, S.; Lopez-Lazaro, M. The coffee constituent chlorogenic acid induces cellular DNA damage and formation of topoisomerase i- and ii-DNA complexes in cells. J. Agric. Food Chem. 2012, 60, 7384-7391. [CrossRef] [PubMed]

72. Hasegawa, T.; Shimada, S.; Ishida, H.; Nakashima, M. Chafuroside b, an oolong tea polyphenol, ameliorates uvb-induced DNA damage and generation of photo-immunosuppression related mediators in human keratinocytes. PLoS ONE 2013, 8, e77308. [CrossRef] [PubMed]

73. Vanella, L.; Barbagallo, I.; Acquaviva, R.; Di Giacomo, C.; Cardile, V.; Abraham, N.G.; Sorrenti, V. Ellagic acid: Cytodifferentiating and antiproliferative effects in human prostatic cancer cell lines. Curr. Pharm. Des. 2013, 19, 2728-2736. [CrossRef] [PubMed]

74. Abib, R.T.; Quincozes-Santos, A.; Zanotto, C.; Zeidan-Chulia, F.; Lunardi, P.S.; Goncalves, C.A.; Gottfried, C. Genoprotective effects of the green tea-derived polyphenol/epicatechin gallate in c6 astroglial cells. J. Med. Food 2010, 13, 1111-1115. [CrossRef] [PubMed]

75. Miene, C.; Weise, A.; Glei, M. Impact of polyphenol metabolites produced by colonic microbiota on expression of cox-2 and gstt2 in human colon cells (1t97). Nutr. Cancer 2011, 63, 653-662. [CrossRef] [PubMed]

76. Hossain, M.Z.; Patel, K.; Kern, S.E. Salivary alpha-amylase, serum albumin, and myoglobin protect against DNA-damaging activities of ingested dietary agents in vitro. Food Chem. Toxicol. 2014, 70, 114-119. [CrossRef] [PubMed]

77. Mohan, S.; Thiagarajan, K.; Chandrasekaran, R. In vitro evaluation of antiproliferative effect of ethyl gallate against human oral squamous carcinoma cell line kb. Nat. Prod. Res. 2015, 29, 366-369. [CrossRef] [PubMed]

78. Zielinska-Przyjemska, M.; Ignatowicz, E.; Krajka-Kuzniak, V.; Baer-Dubowska, W. Effect of tannic acid, resveratrol and its derivatives, on oxidative damage and apoptosis in human neutrophils. Food Chem. Toxicol. 2015, 84, 37-46. [CrossRef] [PubMed]

79. Kumar, D.; Basu, S.; Parija, L.; Rout, D.; Manna, S.; Dandapat, J.; Debata, P.R. Curcumin and ellagic acid synergistically induce ros generation, DNA damage, p53 accumulation and apoptosis in hela cervical carcinoma cells. Biomed. Pharmacother. 2016, 81, 31-37. [CrossRef] [PubMed]

80. Sebastia, N.; Montoro, A.; Hervas, D.; Pantelias, G.; Hatzi, V.I.; Soriano, J.M.; Villaescusa, J.I.; Terzoudi, G.I. Curcumin and trans-resveratrol exert cell cycle-dependent radioprotective or radiosensitizing effects as elucidated by the pcc and g2-assay. Mutat. Res. 2014, 766-767, 49-55. [CrossRef] [PubMed]

81. Lewinska, A.; Wnuk, M.; Grabowska, W.; Zabek, T.; Semik, E.; Sikora, E.; Bielak-Zmijewska, A. Curcumin induces oxidation-dependent cell cycle arrest mediated by sirt7 inhibition of rdna transcription in human aortic smooth muscle cells. Toxicol. Lett. 2015, 233, 227-238. [CrossRef] [PubMed]

82. Sun, B.; Ross, S.M.; Trask, O.J.; Carmichael, P.L.; Dent, M.; White, A.; Andersen, M.E.; Clewell, R.A. Assessing dose-dependent differences in DNA-damage, p53 response and genotoxicity for quercetin and curcumin. Toxicol. In Vitro 2013, 27, 1877-1887. [CrossRef] [PubMed] 
83. Ide, H.; Yu, J.; Lu, Y.; China, T.; Kumamoto, T.; Koseki, T.; Muto, S.; Horie, S. Testosterone augments polyphenol-induced DNA damage response in prostate cancer cell line, LNCaP. Cancer Sci. 2011, 102, 468-471. [CrossRef] [PubMed]

84. Seo, Y.N.; Lee, M.Y. Inhibitory effect of antioxidants on the benz[a]anthracene-induced oxidative DNA damage in lymphocyte. J. Environ. Biol./Acad. Environ. Biol. India 2011, 32, 7-10.

85. Lu, J.J.; Cai, Y.J.; Ding, J. Curcumin induces DNA damage and caffeine-insensitive cell cycle arrest in colorectal carcinoma hct116 cells. Mol. Cell. Biochem. 2011, 354, 247-252. [CrossRef] [PubMed]

86. Lu, J.J.; Cai, Y.J.; Ding, J. The short-time treatment with curcumin sufficiently decreases cell viability, induces apoptosis and copper enhances these effects in multidrug-resistant k562/a02 cells. Mol. Cell. Biochem. 2012, 360, 253-260. [CrossRef] [PubMed]

87. Turkez, H.; Sisman, T. The genoprotective activity of resveratrol on aflatoxin $b(1)$-induced DNA damage in human lymphocytes in vitro. Toxicol. Ind. Health 2012, 28, 474-480. [CrossRef] [PubMed]

88. Chen, C.; Jiang, X.; Hu, Y.; Zhang, Z. The protective role of resveratrol in the sodium arsenite-induced oxidative damage via modulation of intracellular gsh homeostasis. Biol. Trace Element Res. 2013, 155, 119-131. [CrossRef] [PubMed]

89. Demoulin, B.; Hermant, M.; Castrogiovanni, C.; Staudt, C.; Dumont, P. Resveratrol induces DNA damage in colon cancer cells by poisoning topoisomerase ii and activates the atm kinase to trigger p53-dependent apoptosis. Toxicol. In Vitro 2015, 29, 1156-1165. [CrossRef] [PubMed]

90. Rashid, A.; Liu, C.; Sanli, T.; Tsiani, E.; Singh, G.; Bristow, R.G.; Dayes, I.; Lukka, H.; Wright, J.; Tsakiridis, T. Resveratrol enhances prostate cancer cell response to ionizing radiation. Modulation of the ampk, akt and mtor pathways. Radiat. Oncol. 2011, 6, 669-672. [CrossRef] [PubMed]

91. Gonthier, B.; Allibe, N.; Cottet-Rousselle, C.; Lamarche, F.; Nuiry, L.; Barret, L. Specific conditions for resveratrol neuroprotection against ethanol-induced toxicity. J. Toxicol. 2012, 2012, 973134. [CrossRef] [PubMed]

92. Yilmaz, D.; Aydemir, N.C.; Vatan, O.; Tuzun, E.; Bilaloglu, R. Influence of naringin on cadmium-induced genomic damage in human lymphocytes in vitro. Toxicol. Ind. Health 2012, 28, 114-121. [CrossRef] [PubMed]

93. Cristina Marcarini, J.; Ferreira Tsuboy, M.S.; Cabral Luiz, R.; Regina Ribeiro, L.; Beatriz Hoffmann-Campo, C.; Segio Mantovani, M. Investigation of cytotoxic, apoptosis-inducing, genotoxic and protective effects of the flavonoid rutin in htc hepatic cells. Exp. Toxicol. Pathol. 2011, 63, 459-465. [CrossRef] [PubMed]

94. Maeda, J.; Roybal, E.J.; Brents, C.A.; Uesaka, M.; Aizawa, Y.; Kato, T.A. Natural and glucosyl flavonoids inhibit poly(adp-ribose) polymerase activity and induce synthetic lethality in brca mutant cells. Oncol. Rep. 2014, 31, 551-556. [PubMed]

95. Wu, L.Y.; Lu, H.F.; Chou, Y.C.; Shih, Y.L.; Bau, D.T.; Chen, J.C.; Hsu, S.C.; Chung, J.G. Kaempferol induces DNA damage and inhibits DNA repair associated protein expressions in human promyelocytic leukemia hl-60 cells. Am. J. Chin. Med. 2015, 43, 365-382. [CrossRef] [PubMed]

96. Kurzawa-Zegota, M.; Najafzadeh, M.; Baumgartner, A.; Anderson, D. The protective effect of the flavonoids on food-mutagen-induced DNA damage in peripheral blood lymphocytes from colon cancer patients. Food Chem. Toxicol. 2012, 50, 124-129. [CrossRef] [PubMed]

97. Kozics, K.; Valovicova, Z.; Slamenova, D. Structure of flavonoids influences the degree inhibition of benzo(a)pyrene-Induced DNA damage and micronuclei in hepg2 cells. Neoplasma 2011, 58, 516-524. [CrossRef] [PubMed]

98. Kim, J.Y.; Jeon, Y.K.; Jeon, W.; Nam, M.J. Fisetin induces apoptosis in huh-7 cells via downregulation of birc8 and bcl212. Food Chem. Toxicol. 2010, 48, 2259-2264. [CrossRef] [PubMed]

99. Huang, W.W.; Chiu, Y.J.; Fan, M.J.; Lu, H.F.; Yeh, H.F.; Li, K.H.; Chen, P.Y.; Chung, J.G.; Yang, J.S. Kaempferol induced apoptosis via endoplasmic reticulum stress and mitochondria-dependent pathway in human osteosarcoma u-2 os cells. Mol. Nutr. Food Res. 2010, 54, 1585-1595. [CrossRef] [PubMed]

100. Barcelos, G.R.; Grotto, D.; Angeli, J.P.; Serpeloni, J.M.; Rocha, B.A.; Bastos, J.K.; Barbosa, F., Jr. Evaluation of antigenotoxic effects of plant flavonoids quercetin and rutin on hepg2 cells. Phytother. Res. 2011, 25, 1381-1388. [CrossRef] [PubMed]

101. Barcelos, G.R.; Angeli, J.P.; Serpeloni, J.M.; Grotto, D.; Rocha, B.A.; Bastos, J.K.; Knasmuller, S.; Junior, F.B. Quercetin protects human-derived liver cells against mercury-induced DNA-damage and alterations of the redox status. Mutat. Res. 2011, 726, 109-115. [CrossRef] [PubMed] 
102. Ding, M.; Zhao, J.; Bowman, L.; Lu, Y.; Shi, X. Inhibition of ap-1 and mapk signaling and activation of nrf2/are pathway by quercitrin. Int. J. Oncol. 2010, 36, 59-67. [CrossRef] [PubMed]

103. Duthie, S.J.; Johnson, W.; Dobson, V.L. The effect of dietary flavonoids on DNA damage (strand breaks and oxidised pyrimdines) and growth in human cells. Mutat. Res. 1997, 390, 141-151. [CrossRef]

104. Duthie, S.J.; Collins, A.R.; Duthie, G.G.; Dobson, V.L. Quercetin and myricetin protect against hydrogen peroxide-induced DNA damage (strand breaks and oxidised pyrimidines) in human lymphocytes. Mutat. Res. 1997, 393, 223-231. [CrossRef]

(C) 2016 by the authors; licensee MDPI, Basel, Switzerland. This article is an open access article distributed under the terms and conditions of the Creative Commons Attribution (CC-BY) license (http://creativecommons.org/licenses/by/4.0/). 